Ideology and Civilian Victimization in Northern Ireland's Civil War

Anar K. Ahmadov

Faculty of Governance and Global Affairs

Leiden University

anar.ahmadov@gmail.com

James Hughes (corresponding author)

Department of Government

London School of Economics and Political Science

Houghton Street

London

WC2A 2AE

j.hughes@lse.ac.uk tel: oo442079556898

Word Count: 1o,986 


\section{Ideology and Civilian Victimization in Northern Ireland's Civil War}

Abstract

Why do some groups fighting in civil wars target civilians more than others? We propose an explanation that challenges the current focus on material and organizational factors and instead brings back and emphasizes the role of ideology. We argue that the ideological frameworks of armed groups, whether state or non-state, condition their decisions about targeting, in some cases setting normative constraints on action even if such choice involves higher costs and risks. We examine these hypotheses using a mixed-method approach that combines a statistical analysis of a newly constructed disaggregated data set on all fatalities in Northern Ireland's conflict between 1969 and 2005 with a comparative historical study of the interaction between key ideologies and the armed groups that adopted them.

Keywords: ideology; civilian victimization; civil war; Northern Ireland 


\section{Ideology and Civilian Victimization in Northern Ireland's Civil War}

On Sunday, August 10, 2014, in the city of Mayadin in Deir Al Zor province of Syria, the militants from the Islamic State of Iraq and the Levant (Isil) crucified two men from the Al Sheitaat tribe for "dealing with apostates," followed by two others in neighbouring Al Bulel for blasphemy (Gulf News 2014). In subsequent days, Isil, which earlier took over two large oil fields in the province, executed 700 members of the $\mathrm{Al}$ Sheitaat, mostly civilians, by shooting or beheading them (Reuters 2014). Fighting in the same war for apparently similar goals of taking control of territory to build a state, a few dozen miles north from the Isil capital Al-Raqqah, the Kurdish forces - People's Protection Units (YPG) and Women's Protection Units (YPJ) - have largely adhered to strict targeting norms by focusing their war on combatants (HRW 2015). Differences in patterns of violence are endemic across fighting groups in civil wars in various parts of the world (Humphreys and Weinstein 2006), and about 40 per cent of states and rebels exercise restraint in their violence against civilians (Stanton 2009). What accounts for this variation?

There has been a proliferation of theories that aim to solve this puzzle. Studies derived from the "economic turn" in the study of civil war (Azam and Hoeffler 2002) and the “organizational turn” (Humphreys and Weinstein 2006; Weinstein 2007) argue that civilian victimization is determined by material factors and the organization of armed groups. Another influential account stresses the armed groups' control of territory as an explanation for levels and types of violence, with control being associated with better information flows leading to more accurate targeting (Kalyvas 2006). These different strands of research are connected by the role they attribute to ideology, which range from a nuanced downplaying to an outright rejection of ideology as a 
mere rhetorical device. Such de-ideologization has not been unique to civil war studies. It has been part of the larger trend in social sciences that misperceived the advent of a post-ideological world at the end of the Cold War. Yet, few studies of civil war violence that discard the role of ideology systematically account for it.

In this article, we seek to address these theoretical and empirical gaps. Drawing on historical sociology, terrorism research, qualitative comparative work on civil wars, and nascent political science literature that aims to correct the lacuna in research on civil wars by reaffirming the importance, if not centrality, of political and ideological factors (Balcells 2010; 2011; Thaler 2012; Sanín and Wood 2014; Staniland 2015), we theorize that armed group ideology is a critical factor explaining the variation in civilian victimization across groups. We conceptualize ideology as a "shared framework of mental models that groups of individuals possess that provides both an interpretation of the environment and a prescription as to how that environment should be structured" (Joost et al 2009, 24; Freeden 2003). We argue that armed group ideology is a key factor accounting for variation in civilian victimization across armed groups in civil wars. The targeting patterns of belligerents are conditioned by their ideologies which simplify, shape, and crystallize salient or latent social cleavages and thus identify who and what is a "legitimate target" given their actual or potential opposition to the belligerents' cause. Furthermore, ideology affects targeting patterns through filtering the belligerents' strategy set, because the interpretation of the environment and its remolded "ideal state" image enable some options and discard others. Finally, ideologies can also shape the economic, strategic, and organizational choices of belligerents rather than being separate from or endogenous to them. 
What elements of ideology might facilitate restraint or non-discrimination in violence, and how does this operate in practice? We examine the hypothesis that group ideology explains civilian victimization using a mixed-method approach. We combine a statistical analysis of a sub-national and group-level dataset of fatalities in Northern Ireland's conflict between 1969 and 2005 constructed by us from existing sources, with a brief comparative historical study of the interaction between the two key broad ideologies at the heart of the conflict, loyalist and nationalist. Although a number of different elements of an ideology can ultimately matter depending on the context, in the case of Northern Ireland's civil war, we conjecture that path dependent norms, armed group recruitment, and the nature of relations with the state were key elements in mediating the relationship between armed group ideology and targeting patterns. Inclusivity and non-sectarianism adopted early on as norms were likely to be fortified through path dependence. In interaction with the conflict environment, ideological positions were also likely to affect recruitment patterns and types of recruits, which in turn were likely to shape strategic and tactical choices through which the members of an armed group pursue its goals vis-à-vis targeting. Finally, the nature of relations with the state forces was likely to affect the targeting patterns through shaping the armed group's view on who constitutes a legitimate target, the group's recruitment, and its discipline.

Regarding our dependent variable, even under international norms and laws of war, who counts as a civilian in an armed conflict is contested (ICRC 2015; Petersen 2001). A non-combatant is usually used as a synonym for civilian, but what of cases where combatants are "off-duty", or civilians are armed or contributing in a significant way to combat operations. In Northern Ireland there is no consensus on many of the key 
issues relating to the conflict, including who counts as a "legitimate target", what counts as "sectarianism", and even who counts as a "victim" (see Bruce 1997, Drake 1998, O’Duffy 1995, O’Leary 2005, White 1997, Bloomfield 1998). We adopt a conservative definition of "civilian" here that obviously excludes combatants (members of state security forces, including army, police, and other security agencies, members of republican armed groups, and members of loyalist armed groups), whether on or off duty, but also excludes former paramilitaries, alleged informers, ex-security forces personnel, and armed group-associated politicians. We also check the robustness of our results to alternative definitions.

We find that fighting group ideologies are the most robust predictors of civilian victimization, controlling for other factors. Armed groups with a loyalist ideology were consistently more likely to target civilians and engage in cross-ethnic attacks on civilians, while republican armed groups were significantly less likely to target civilians and significantly more likely to target combatants. These results survive multiple robustness checks. We trace these targeting differences to path-dependent ideological norms, recruitment patterns, and relations with the British armed forces during the conflict. We suggest that republican armed group restraint in targeting is a product of an ideological framework which claims to be inclusive and non-sectarian, stressing the colonial nature of the conflict and the subaltern position of civilians across communities involved in the conflict. Conversely, the armed groups with loyalist ideology were less likely to show restraint in civilian victimization because this ideology crystallizes defensive attitudes that demarcate the differences between civilians in different communities, and do not eschew sectarian beliefs. 
In contrast to other key works in this field, we show empirically the autonomous effect of group ideology on civilian victimization in civil wars while systematically accounting for alternative explanations. For example, while Thaler argues that ideology shapes the use of selective versus indiscriminate violence, his findings are limited given his qualitative analysis of only two groups in two different contexts (Thaler 2012) - Frelimo in Mozambique and the Movimento Popular de Libertação de Angola in Angola, and because such analysis does not systematically account for other factors. We rectify this by examining the targeting behavior of fifteen different armed groups fighting in the same civil war and by explicitly and simultaneously controlling for their various characteristics. Thus, our research also contributes to promoting micro-level analyses for understanding the underpinnings of civil war violence (Kalyvas 20o6: 6; Cederman and Gleditsch 2009).

Our research seeks to significantly advance the debates on patterns of violence in the conflict in Northern Ireland, which is one of the most studied from an area studies perspective, but as yet poorly integrated into the comparative study of civil war. Our contribution here is twofold. Firstly, a number of studies have argued that ideological differences are important factors in decoding the patterns of violence in this conflict; others have disputed this; and some studies have not been immune to ideological biases themselves (see Bruce 1997; Drake 1998; O’Duffy 1995; O’Leary 2005; White 1997). However, their research designs - centered on broad qualitative explorations and bivariate correlations that do not systematically account for potential confounders - are in effect descriptive rather than explanatory: they do not allow assessment of the independent effects of different factors. Our study presents findings arrived at through a research design that evaluates the role of different factors in a systematic and explicit 
fashion. Second, it is based on a novel dataset that combines the strengths of all existing sources of data on the fatalities in the Northern Ireland conflict and includes original components that code the characteristics of armed groups and localities of civilian victimization.

\section{THEORIES OF CIVILIAN VICTIMIZATION}

A fundamental assumption in the study of intra-state conflict is that the support of the general population for a belligerent party is an asset that is critical to the success of that party (see Lawrence 1920; Mao 1961; Mason 1996; Migdal 1974; for recent studies, see Valentino et al. 2004; Kalyvas and Kocher 2007; Downes 2006). Therefore, if insurgents enjoy support from a community, they are expected to be less likely to engage in civilian victimization of that community. On the other hand, if enemy forces perceive that a local community supports their rival, they can raise the costs of such support by punishing civilians from that community (Valentino et al. 2004; Balcells 2010). In addition, ethnic affiliation can be key to targeting because it can serve as a crude shortcut to identifying groups of suspected enemy supporters when ideological affiliations are not known for certain (Fjelde and Hultman 2014). Overall, armed groups are less likely to target co-ethnic civilians or their ideological home communities, especially when these serve as their recruitment base (Stanton 2015). The influential study of civil wars by Kalyvas downplayed the role of ideological and ethnic factors in targeting, instead postulating that the scale of indiscriminate violence in civil wars depends on the degree of control that a belligerent exercises over territory: the less territorial control there is, the more likely it is that there will be "indirect" indiscriminate targeting resulting in higher levels of civilian victimization (Kalyvas 2006; see also Balcells 2010). Other scholars have stressed the role of the belligerents' 
capabilities in shaping patterns of violence against civilians, with weak or weakening capacity of belligerents resulting in more indiscriminate violence caused by the groups' operations and through deliberate strategies of victimizing civilians to close the “capability gap” (Wood, 2010; 2014; see also Hultman 2012).

However, capabilities derive partly from material sources, and depending on the source, armed groups may be more or less prone to target civilians. Groups which secure external funding - such as natural resource rents or foreign sponsorship - may be more likely to target civilians than groups that rely on the local populations for material support (Azam and Hoeffler 2002; Weinstein 2007; Wood 2010). Yet, different forms of external funding - e.g., foreign aid or lootable resources - may have different effects (Wood 2010; Salehyan et al. 2014). The number of donors and their characteristics can matter, too (Salehyan et al. 2014). A similar logic may apply to governments, not just insurgents: larger resources, such as overseas development aid, may increase the capacity of governments to defeat insurgents (Azam and Hoeffler 2002; Fearon and Laitin 2003). Violence against civilians can also depend on the organizational characteristics of combatants: material incentives in recruitment, ethnic heterogeneity, and lack of disciplinary mechanisms within warring groups can entail higher civilian abuse (Humphreys and Weinstein 2006; for intellectual precursors of this idea, see Machiavelli 2005: 51; Mao 1961: 93).

\section{WHY IDEOLOGY MATTERS}

Much of the civil war scholarship in political science and economics at the end of the $20^{\text {th }}$ century and the first decade of the $21^{\text {st }}$ assumes rational self-seeking motivations of leaders, recruits, and groups in initiating, joining, or conducting civil war, thus either 
relegating ideational and other-regarding preferences to a role of explaining residual variation or discarding them altogether. Why this assumption took hold can probably be traced to five factors. Firstly, it was a reaction to what was seen as the unsystematic examination of ideological explanations in much of the historical and qualitative literature on civil wars, where the importance of ideology is taken as a convention. Second, it followed a seeming de-ideologization of the international system in the wake of the fall of communism and a seeming "end of history" triumph of liberal democracy. Third, and related to the previous point, it reflected a new hegemonic focus in Western scholarship that shifted the lens from revolution to predation in understanding civil war: from "ideological Che Guevaras in favor of the predatory Charles Taylors" (Kalyvas and Balcells 2010, 420). This paradigm shifting in turn reflected actual changes: the fall of communism, the shattering of Marxist ideologies and end of the Cold War undermined the core foundations of secular revolutionary movements, and ended the abundant material support from the Superpowers, which in turn induced other forms of raising funds that forged and advantaged the Charles Taylor types (Przeworski 1991, 100; Kalyvas and Balcells 2010, 421). Fourth, the prevailing assumption of self-seeking motivations as the core explanation for human behavior mirrored mainstream beliefs in economics, which heavily influenced political science research (Sanín and Wood 2014). Finally, such assumptions were partly reinforced by a lack of disaggregated data as well as poor conceptualization, weak design, and doubtful proxies. Many studies that emphasized micro-level foundations in fact used suboptimal country-level proxies (for nuanced critiques, see Buhaug et al. 2008; Cederman and Gleditsch 2009). 
However, a recent study by Sanín and Wood suggests that ideology can matter in civil wars in general, noting that ideologies may constrain the group from violence altogether or may justify violent over nonviolent strategies (Sanín and Wood 2014). Regarding the conflict onset, for example, the combination of nationalism - an ideology of political self-rule (Wimmer 2013) - and democratization can make newly democratizing states prone to inter-state violence and civil war (Mansfield and Snyder 1995; Snyder 2000; Wimmer 2013). Evidence from India and Pakistan also suggests that patterns of militia-state relations depend heavily on ruling elites' ideological projects (Staniland 2015). Revolutionary beliefs constitute a critical component of robust insurgency (Kalyvas and Balcells 2010, 420) because cognitive frames and ideologies can arouse "passionate ideological commitments among combatants, both domestically and internationally" (Hironaka 2005, 123). Ideology can shape armed groups' recruitment, behavior, and retention of forces (Ugarriza and Craig 2012). In Colombia, recruits who joined for ideological reasons were less likely to defect and more likely to switch sides or demobilize if they perceived their group as deviating from its ideological principles (Oppenheim et al. 2015). By boosting combat morale, ideology can be a force multiplier, increasing the combat capacity of the group (Taber, 2002). Ideology can also be crucial in determining the allegiances of civilians and their role in the production of violence (Staniland 2015; Sanín and Wood 2014). Civil wars can be more protracted when rebels recruit from and fight on behalf of excluded ethnic groups because in such cases rebels have stronger collective solidarity and higher risk tolerance (Wucherpfennig et al. 2012). Finally, and importantly, in terrorism research ideology has been identified as one of the key factors in target selection (Asal et al. 2008; Drake 1998; Sánchez-Cuenca and De la Calle 2009; Juergensmeyer 2017). 
We argue that ideology is also an overlooked factor in accounting for different patterns of targeting in civil wars. First, the ideologies generated or adopted by armed groups are likely to create threat perceptions that determine decisions about who friends and foes are and, thus, who legitimate targets potentially are in violent conflict. Ideology frames the preferences and beliefs of belligerents, shapes debates about the nature of community, and identifies the end goal of an armed insurgency. In civil wars, the targeting by armed groups is likely to reflect salient or latent political cleavages within a society, and the more so, the higher is the extent to which these cleavages have been crystallized in ideologies.

While geographic areas can mark ethnic or political constituency territories (Humphreys and Weinstein 2006; Fjelde and Hultman 2014), focusing on them may not reveal important differences in who exactly is targeted by armed groups. It is not likely to be any civilian who will be subject to violence within a given area but rather the civilians of a particular social group who are associated in the eyes of the perpetrating belligerent with a particular enemy. Contrary to assumptions of many existing studies, we hold that in civil wars the conceptual clustering of civilians into homogenous groups of "civilian population" or "local population" is misplaced, even within a given geographic or constituency area. If the salient and mobilized cleavages are ethnic or religious, for example, then we should expect these to be reflected in patterns of violence regardless of geography. We surmise that an armed group is more (or less) likely to victimize a civilian if the civilian is a member of the group which the armed group identifies as hostile (or supportive) to its cause. 
Yet, an armed group's treatment of civilians of a specific group as opponents or of civilians in general as irrelevant actors is not likely to automatically lead to their targeting by the armed group. We differ from the analyses of Balcells, and Fjelde and Hultman (Balcells 2010 and Fjelde and Hultman 2014) in arguing that belligerents' ideology affects their targeting patterns also by filtering their strategy set and that some types of violence are excluded from a belligerent's repertoire of violence, not because they would not have strategic benefit or may incur punitive costs, but because their use would undermine the group's ideological commitments, particularly its identity and values as a certain kind of ideological or moral force. Targeting civilians or engaging in rape may be proscribed by the belligerent group because its ideology includes a claim to better represent and govern civilians than its adversaries. More fundamentally, its ideology may constrain the group from civilian violence altogether and justify nonviolent over violent strategies (Sanín and Wood 2014). However, since ideological commitments are norms, with some prescribing restraint, while others sanction non-restraint and excess, different ideologies constrain and others increase the likelihood of civilian victimization (Asal et al. 2015). This applies to victimization both of civilians in general and of civilians of a specific group seen as opponents.

The next logical question is: which ideologies are more and which are less conducive to civilian victimization? While this can ultimately be an empirical question, the prospects of building an ex ante taxonomy of ideologies by their likelihood of entailing civilian victimization and without due attention to the particular context is complicated at best and can be counterproductive. As Drake argues in the case of terrorist organizations, the targeting patterns might differ not only between groups with different ideologies, but also between organizations with apparently similar 
beliefs, such as the communist groups in Europe between 1970s and 1990s, because “ideology and strategy have been adapted to local conditions" (Drake 1998, 70-71). Similarly, conceptualizing them in broad categories, such as "religious ideologies" or "groups with a democratic ideology" (Asal et al. 2015), is likely to be misguided as it is plausible that while one religious ideology prescribes targeting of civilians, another strongly proscribes it. Therefore, to understand its effect on civilian victimization we may need an understanding of what the armed group's ideology is in a particular conflict context, and how it orders the worlds of the belligerents and shapes the normative environment in which violence is enacted. Consequently, we advance our empirical expectations within a specific conflict context.

Furthermore, the extent to which ideological differences explain variation in group institutions, perceptions of and responses to strategic incentives, and processes of mobilization in civil wars is yet under-explored (Blattman and Miguel 2010). Such differences are often treated as exogenous with little effort to assess their possibly ideological origins (Sanín and Wood 2014). This is an important question, the answering of which can help avoid attributing violence against civilians to epiphenomenal factors. For instance, recruitment and discipline may depend on prior ideological commitment or the ideological projects of belligerents. Groups can choose to organize around common goals, to form ethnically homogenous units, and to set in place disciplinary structures due to their ideological commitments (see Sanín and Wood 2014). For example, studies of Islamist violence find that religious sectarianism underpins organizational structures of armed Islamist groups (Juergensmeyer 2017), as well as providing strategic guidance about how and where it is legitimate to fight jihad 
(Hegghammer 2013). However, the relationship between ideology and indiscriminate violence in Islamist armed groups is poorly understood and theorized.

\section{EXPLAINING CIVILIAN VICTIMIZATION IN NORTHERN IRELAND: RESEARCH DESIGN}

Given the complex nature and dynamics of civil wars, understanding the patterns of civilian victimization is complicated by the difficulty of obtaining accurate micro-level data on victims, characteristics of the perpetrators, and the locations where the victimization took place. In this article, we use an original dataset that combines micro-level evidence on all killings in Northern Ireland's civil war and on fifteen organizations responsible for them. Examining the patterns of violence against civilians across multiple groups of perpetrators within the same civil war - as opposed to studying the behavior of different groups in different contexts - has an advantage of helping isolate the effects of group-level factors from country- or international-level institutional, political, and social differences that potentially affect civilian victimization patterns. In line with our theoretical reasoning, focusing the analysis on the sub-national level also helps to see the meaning and impact of ideology, if any, in context.

\section{Northern Ireland's “Long War”}

Three reasons make the case of Northern Ireland's 'Long War" a fertile ground for studying the causes of civilian victimization in civil wars. First, the conflict involved a range of different fighting factions that exhibited different capabilities, sources of funding, organizational structures, etc. Second, there was a significant variation in civilian victimization patterns across armed blocs, specific organizations, time, and location. Finally, the availability of wide-ranging data sources on fatalities of the 
Northern Ireland conflict from three different sources (McKeown 2009; Sutton 2001; McKittrick et al. 2001) enables a systematic micro-level analysis of the covariates of civilian targeting. ${ }^{1}$

The targeting patterns of armed groups in Northern Ireland have been subject to considerable debate. The focus has been on the extent to which major loyalist and republican armed groups were ideological in their use of violence against the Catholic and Protestant communities, respectively. On the one hand, White contends that the Provisional Irish Republican Army's (PIRA) attacks reveal a pattern of non-sectarian targeting of its key strategic adversary - state security forces, while the loyalist paramilitaries were sectarian in their victim selection (White 1997). Focusing on PIRA violence, O'Leary argues that IRA violence "has been primarily strategic, aimed at its official legitimate targets, rather than sectarian” (O’Leary 2005, 239). However, according to Bruce, since the majority of local security force personnel were Protestants, their targeting by PIRA should be seen as sectarian as well (Bruce 1997, 6265). O'Duffy finds that instrumental, tactical and strategic choices related to ethnonational goals rather than affective factors governed the targeting patterns by both republican and loyalist paramilitaries (O'Duffy 1995, 743). Drake largely builds on the previous accounts to argue for an explicit role of ideology as a primary factor motivating target selection for terrorist groups in Northern Ireland and beyond (Drake 1998).

Several problems complicate drawing conclusions from these studies. First, since their methodologies are based mostly on correlations, they do not allow accounting systematically for the role of other group-level factors. Second, the violence of state forces as well as by smaller paramilitary groups is largely absent from systematic incorporation into these studies. Yet, since state forces are belligerents and adopt 
coercive strategies similar to those of non-state actors (Tilly 2004), we do not see an $a$ priori reason for excluding them from the analysis. Third, there is little systematic disaggregation by organization within each camp, despite their significant differences. Fourth, by framing the issue around the term "sectarianism" many studies seem to suggest the prevalence of ideological factors, but the role of ideology in explaining varying levels of civilian victimization remains under-theorized and under-investigated empirically. Finally, while some studies take precaution to avoid this (for example, Drake 1998, 68-69), in effect the term "sectarianism" is often applied loosely, to denote perpetration of any violence across ethnic or religious divides whatever the intention. However, such violence may not necessarily be deliberate or selective and may result from a motivation entirely different from aiming to inflict damage onto a member of a rival ethnic group, such as when acts of economic sabotage or other attacks cause collateral damage.

\section{Dependent Variable: Measuring Civilian Victimization}

We operationalize civilian victimization as lethal violence against civilians. Clearly, victimization is not confined to killing but can include a repertoire of violent acts and abusive behavior, from ethnic cleansing and mass repression to search and seizure policies and systematic harassment. We take lethal violence as a form of victimization that is one of the most indicative of the perpetrators' ideological predispositions and which is also unambiguous.

Our dependent variable is a binary indicating whether an individual victim is a civilian. In civil wars and insurgencies, it is typical that some individuals straddle the divide between combatant and non-combatant, for example seasonal fighters, or the so-called "weekend warriors." In addition, often "non-combatant" is understood as being 
synonymous with "civilian," yet the two concepts differ (ICRC 2015; Petersen (2001) offers a useful framework). In our main analysis, we adopt a conservative definition and code non-combatant victims as "civilian" if they were not former paramilitaries, alleged informers, ex-security service personnel, and armed group-associated politicians. ${ }^{2}$ Focusing on individuals rather than more general counts of casualties allows analyzing covariates of targeting on a finer, micro level.

\section{Independent Variables and Empirical Expectations}

To test the hypothesis on the role of ideology in civilian victimization, we code two variables indicating whether the ideology of the armed group responsible for killing the victim embraced republicanism or loyalism.

While specific organizations in each camp combined different ideological precepts, early on these two ideologies emerged as the key belief systems connecting armed groups within the two ethno-national camps. Irish republicanism came to dominate radical nationalism in the Catholic community. Loyalist armed groups amalgamated the two main ideologies within the Protestant community, British unionism and Ulster loyalism, but differed in the emphasis they put on each (Todd 1987). In our analysis, only loyalist paramilitaries are associated with unionism, however, given their composition and stance within the conflict, state forces - treated here as a separate armed bloc - can also be argued to have adhered to unionism. There were differences in ideological motivation between locally-recruited soldiers of the UDR (mainly Northern Irish Protestants, some of whom were linked to loyalist paramilitaries) and the British Army more broadly. Even the British Army, however, exhibited unionist and sectarian values. The key British Army report on its role in the conflict noted that the prevailing tendency in the army in the early years of the conflict was to "sort the 
Micks out" (Operation Banner, 2006, 8-11). We explore the issue of state forces' unionism in robustness checks of our main findings.

We expect that republicanism and loyalism will be strong predictors of civilian victimization, controlling for other factors, and that they are likely to differ in whether they predisposed armed groups to the victimization of civilians in general and of civilians of Catholic and Protestant background in particular. We conjecture that in practice, from the early phase of the conflict, republican and loyalist ideologies differed sharply on the emphasis they put on the subaltern status of Irish people across communities, inclusiveness for different communities in Northern Ireland, and nonsectarianism. This predisposed armed groups embracing the former ideology to focus on targeting combatants and be restrained in violence against civilians. We explore the elements of these ideological differences in the later sections.

\section{The Data: Fatalities, Organizations, and Constituencies}

Our dataset, constructed between 2008 and 2015, has three components. The first component contains data on all 3,702 fatalities in the Northern Ireland conflict between 1969 and 2005 and is created from the merger of three existing sources by McKeown (2009), Sutton (2001), and McKittrick et al. (2001). While the first two are datasets, the latter provides detailed qualitative information on all fatalities, which we used for coding new variables. Since we systematically checked and corrected inconsistencies, our dataset combines the strengths of these separate sources, reduces their weaknesses through streamlining and superior coding, and adds new variables. ${ }^{3}$ Our dataset allows us to go beyond counts of casualties conventionally resorted to in existing studies due to the lack of micro-level data and analyze the covariates of targeting at the individual victim level. 
The second component contains details on fifteen organizations responsible for killings during the conflict. This allows us to analyze evidence on two levels: the more specific fighting group level and the broader level by fighting blocs - loyalist, republican, and state forces. The group-level variables, including the organization's base territories, co-ethnic areas, capabilities, external resources, structure, and ideology, were coded through an extensive study and triangulation of a large array of government, media, and academic sources. In a departure from much of the existing literature, and following Tilly (2004), our definition of an armed group includes the state security forces - British Army, Royal Ulster Constabulary (RUC), and Ulster Defence Regiment (UDR). ${ }^{4}$

Finally, the third component is made up of variables on eighteen Northern Ireland parliamentary constituencies, ${ }^{5}$ such as their population size, religious breakdown, electoral support for unionist and nationalist parties, military presence, and so on, that date back to 1969 and are coded from a variety of census and electoral data. This component allows exploring sub-national variation in civilian victimization, particularly in combination with the characteristics of armed groups.

Throughout the analysis we distinguish six periods of the conflict defined by key shaping policies or events: from the onset of mass violence in summer 1969 to the end of 1971; from Bloody Sunday in January 1972 until the introduction of the policies of Ulsterization, "normalization" and "criminalization" in late 1975; 1976 to the republican hunger strikes in $1981 ; 1982$ to the end of 1989, when the British government admitted that the PIRA could not be defeated militarily; 1990 to the 1998 Good Friday Agreement (GFA); and post-1998 until the end of 2005 when PIRA and subsequently other major groups declared the end of their armed campaigns and confirmed decommissioning of their weapons and the "end of the war." 


\section{Patterns of Violence}

Figure 1 shows that there was a significant variation in civilian victimization between different armed blocs and time periods, with republican paramilitaries responsible for the largest number of casualties overall and loyalist paramilitaries responsible for the largest number of civilian casualties. State forces were responsible for fewer civilian killings compared with the loyalist and republican armed blocs and were more likely than loyalist paramilitaries to target combatants. These patterns remain similar when we narrow the analysis down to the case of volitional violence, the "incidents where the victim's death was clearly envisaged and deliberately procured" (McKeown 20o9, $11)$.

\section{[Figure 1]}

Equally important is to determine who targeted whom. Figure 2 relates targeting by the three armed blocs to the victimized noncombatants' religious background. It suggests four key patterns.

First, in each period loyalist paramilitaries targeted considerably more Catholic civilians. Similarly, republican paramilitaries were more likely to target Protestant civilians, but proportions by civilians' ethno-religious background are not as stark. Second, state forces targeted disproportionately more Catholic civilians. These patterns also apply to volitional violence. However, the majority of loyalist paramilitaries' targets were volitional throughout the conflict, with the same proportions as in the case of general violence. Roughly the same holds for state forces and less so for republican paramilitaries.

[Figure 2]

Figure 3 shows the spatial distribution in civilian casualties and suggests considerable variation across different areas, armed blocs, and ethno-religious groups. However, as 
Humphreys and Weinstein (2007) note, "it is unsatisfactory to account for variation in the abuse of civilians simply by saying that the CDF acted one way while the RUF acted another. At best, this is description not explanation" (434). The question is: what characteristics of armed groups and their environment made some more disposed than others to victimize civilians?

[Figure 3]

\section{Quantitative Study and Control Variables}

To test different hypotheses on civilian victimization, we estimate multivariate logistic regression models where ideological factors are our independent variables. Our control variables account for each of the alternative explanations. Home measures whether the victimization took place in the constituency where the perpetrator armed group had a key base. Co-ethnic Area indicates whether the constituency in which the victimization took place had a majority population that was co-ethnic with the perpetrator armed group. Following Humphreys and Weinstein (2007), Dominance measures the perpetrator group's extent of territorial control in the constituency. Size (logged) is based on the estimated average active membership of the perpetrator group during the course of the conflict. Experience indicates whether the perpetrator group members on average had military experience. External Support indicates whether there is consistent evidence that the group received such support from outside the UK. Some groups also raised funds through organized crime and this is proxied by Crime Rents. Finally, we code two dichotomous measures of internal characteristics of armed groups drawn from existing sources - Coherent Structure and Discipline. ${ }^{6}$

\section{Qualitative Study}


To complement our quantitative analysis and identify causal processes that potentially linked ideologies to the violence against civilians, we undertake a brief historical study of reproduction, development and effects of republican and loyalist ideologies. Beyond a few solid historical studies of individual ideological traditions, there is paucity of systematic research on this topic, defying solid conclusions about ideology's effect on the dynamics of violence in the conflict in the Northern Ireland case. To probe and reconstruct potential links, we draw on existing secondary literature, survey evidence, government documents, and memoirs. Given the exploratory nature of our qualitative analysis and the space limitations, we report only the findings, and these are schematic and tentative, but, we hope, insightful and indicative nonetheless.

\section{QUANTITATIVE ANALYSIS}

First, we evaluate the relationships between each explanatory variable and civilian victimization after controlling for all other variables, except group ideology, as well as for the period and location effects (Table 1, models 1 and 4 ). This allows exploring the potential role of each factor when ideology is not accounted for, and then comparing these patterns to those found in the existing literature. Subsequent models $(2-3,5-6)$ control for the potential effect of group ideology. We estimate separate models with republicanism and loyalism because, given their strong correlation, estimating their effects in the same model can bias estimates and result in extremely large odds ratios. Since our variables on armed groups are somewhat correlated, we are careful not to attribute much to the exact size of odds ratio as they may not be sufficiently reliable. Still, we look at the overall substantive and statistical significance of each effect in comparison to those of other variables. Finally, to examine whether different group ideologies are associated with victimizing civilians of different ethno-religious 
backgrounds, we estimate separate models with dependent variables that indicate the civilian victims' belonging to different ethno-religious groups (Table 2).

[Table 1]

In both sets of specifications in Table 1 and 2, we estimate models for all violence and separately for volitional violence for a more fine-grained analysis. Such a separation is important to help infer intention from the incident of killing and thus distinguish deliberate targeting from collateral damage or mistakes because it is possible that the civilian death toll due to loyalist violence is inflated by two factors. Firstly, as Bruce has pointed out, "the anti-state group has a much bigger target to aim at. The bigger the target, the more likely you are to hit it." (Bruce, 1997, 63). Republican armed groups operated in a target rich environment, with a wide range of categories that fell within the accepted remit of "legitimate" target, which also was a good fit with republicans' ideologically defined target orbit of the "British war machine" e.g. British army, RUC, UDR, prison wardens, judges, civil servants, etc. Loyalists, in contrast, to adhere to principles of discrimination in their targeting which would minimise civilian casualties were required to focus their violence against nationalist/republican combatants. While this was the morally correct option, given that loyalists did not do this, the question is whether this was a feasible strategy in the conditions of the conflict. Bruce has also highlighted these groups' potential incompetence, mistakes in identification, or lack of information (Bruce 1997, 6o-61). The lack of combatant targets does not appear to us to negate the moral imperative of adhering to constraints on targeting civilians. In recent years, it has also become clear that there was close collusion between loyalist paramilitaries and key intelligence sections of the RUC and British Army throughout the conflict, suggesting that loyalists did have the information required to direct their violence in a more discriminatory way, but rarely availed themselves of the 
opportunity to do so. Notwithstanding arguments from both sides, we treat this as a question that requires a systematic investigation and this is what we aim for by considering volitional violence separately. Loyalist killings also exhibited a higher frequency of direct personal killing through assassination, beatings, kidnapping/dumping, and stabbing, compared with republican violence (Figure 4).

In all models, we weight observations by the number of killings by each armed group to take into account varying lethality across groups. To account for waves of violence, we allow for the possibility of correlation across killings in a given year. ${ }^{7}$ All models use robust standard errors clustered by year and control for period and location (not reported). These measures help tackle potential temporal and spatial autocorrelation (Wooldridge 2010). The models exhibit good fit: the percent correctly predicted stays mostly well above 70 and areas under the ROC curve (AUROC) fall either between 0.70-0.80, exhibiting fair fit, or 0.80-0.90, showing good fit (Zhou et al. 2009).

Consistent with our expectations, we find a substantively and statistically strong relationship between group ideology and civilian victimization. Republicanism is associated with a smaller likelihood of civilian victimization, compared to the other two armed blocs - loyalist groups and the state forces. Loyalism, on the other hand, is associated with larger odds of civilian victimization, controlling for other factors, compared to republican groups and the state forces. The relationship between group ideology and civilian victimization emerges, along with Co-ethnic Area, as the only consistently strong relationship. These differences are starker when we consider only volitional violence. 
However, considering civilian killings without regard to their background may conceal important distinctions. Since an armed group may be more likely to victimize outgroup civilians as the latter may be seen as more likely to be hostile to the armed group's cause and, conversely, less likely to victimize in-group civilians assumed to be supportive of this cause, in the case of Northern Ireland we may need to disaggregate civilians by religious background. Here we find evidence of proneness to cross-ethnic targeting on both sides, with caveats (Table 2). Having a republican ideology significantly increases the odds of victimizing a Protestant civilian, and reduces the group's odds of victimizing a Catholic civilian. Conversely, if a victimized civilian was a Catholic, the odds that the perpetrator armed group had a loyalist ideology increase significantly. However, loyalist groups were not more or less likely to victimize Protestant civilians. These differences are more pronounced when we consider only volitional violence. Overall, the comparison of the size of odds ratios for loyalism and republicanism - for example, 2.839 in Model 2 and 12.745 in Model 3 - suggests that loyalist groups were more disposed to cross-ethnic civilian targeting.

\section{[Table 2]}

The results also help cast light on the role of other factors, all of which, except CoEthnic Area, find little or mixed empirical support. When ideology is not accounted for, we find that Experience, External Support, Discipline, and Crime Rents are associated with victimizing a civilian, albeit not always in hypothesized ways. These effects find little support once we include ideology as a factor. ${ }^{8}$ However, we find consistently strong empirical support for the hypothesis that fighting groups were less likely to victimize civilians in geographic areas where they had more co-ethnics among the members of the local community. When civilians are disaggregated by their ethnoreligious background, the effect of Co-ethnic Area is no longer statistically significant. 
There is also some indication that larger groups were less likely to kill civilians. We do not find any support in our data for the role of other factors.

\section{Robustness Checks}

One of the key concerns may be that our results on the importance of ideology depend on the measurement of the dependent variable. Specifically, while RUC and UDR members were combatants, it is possible that their targeting by republican paramilitaries had to do not (only) with their status as security force members, but, given the predominantly Protestant composition of these forces (around 93 per cent in the case of the RUC), also with the ethnic identity of most of them (Bruce 1997, 62-65). We address this concern by re-estimating our core model with dependent variables Civilians and Protestant Civilian2, which regard victims who were serving in RUC and UDR as civilians.

The main results survive this test well (Table 3 ). In the case of general civilian victimization (columns 1-2), the odds ratios somewhat increase for republicanism and decrease for loyalism, but otherwise the results are essentially unchanged. In the case of Protestant civilian victimization (columns 3-4), two changes take place. First, while odds ratio for republicanism increases significantly, it stays below loyalism in the case of victimizing Catholic civilians (i.e., 5.577 in Table 3, column 3 vs. 12.745 in Table 2, column 3). Second, the odds ratio for loyalism is significantly below 1 and is statistically significant, suggesting that loyalist groups were significantly less likely to target RUC and UDR. 
Since the state forces consisted of predominantly Protestant personnel and were significantly less violent as the conflict developed, coding only the paramilitaries as carriers of ideology can create an upward bias, making loyalism seem more associated with civilian victimization. To rectify this, we replicate the main results with unionism which includes the state forces as well as loyalist paramilitaries as carriers of unionist ideology (column 5). The results change in the opposite direction than hypothesized the odds of victimizing civilians when the group is unionist actually increase. ${ }^{9}$

Next, we examine whether the effect of ideology on patterns of targeting changed after the introduction of Ulsterization, "normalization" and "criminalization" policies in 1975 (columns 6-7). Indeed, the results change, but partially, and the direction of effects stays the same. The results also remain largely unchanged when we re-estimate the baseline model after controlling for the degree of parity (Ballcels 2010; 2011) between Catholic and Protestant populations (columns 1-2); focus only on Northern Ireland regions (e.g. the "murder triangle") ${ }^{10}$ where Kalyvas (2006) has claimed that a large number of killings were motivated by personal animosities (columns 3-4); conceptualize the dependent variable in broader Noncombatant terms that includes former paramilitaries, alleged informers, politicians and ex-security service persons as well as civilians (columns 5 -6); focus on civilians killed in attacks where sectarian motives could be reasonably established, according to McKeown (2009) (columns 7-8); adopt alternative periodization based on exact dates (columns 9-10); substitute Home with a variable Homez constructed to reflect electoral support to loyalist and nationalist parties in the 1970 Westminister elections (columns 11-12); and substitute Home with a variable Homez, where none of the constituencies in Northern Ireland are coded as a home for the British Army, RUC, and UDR (columns 13-14). 
[Table 3]

\section{QUALITATIVE ANALYSIS: UNDERSTANDING THE IMPACT OF IDEOLOGY}

Irish republicanism and loyalism ostensibly have many commonalities, with a spectrum of subsets of radical, moderate, secular and religious elements within each. Both emerged in the early modern period of European history, in the sixteenth and seventeenth centuries, during struggles over the nature of the state and government characterized by the shift from monarchical to more limited or republican forms of government. Both also make fundamental claims that the principles of religious and civil liberties for all are sacrosanct. The fundamental ideological claims mirror the other and appear inclusive. However, if they are similar, how can we account for their different associations with the violence against civilians? We trace these differences to the interplay between three factors informed by the ideological commitments in practice - path dependency in norms, recruitment patterns, and alliance with the state.

\section{Path-Dependent Norms}

While emerging in the same context, the positions of republicanism and loyalism in the context of struggle between indigenous and settler-colonist peoples entailed a number of differences. Rooted in the civic ideology of the French Revolution, and founded by mainly Protestant elite members, republicanism also subsumed the elements of nineteenth century nationalism. It emphasized the subaltern status of all Irish people, thus stressing inclusiveness of different communities in Ireland and with its anti-colonialist strand focused its energies against imperial control. These tenets entailed disinclination towards violence against members of the community that would make the imagined community of an independent Ireland. From their 
crystallization under the Fenian Movement and the Irish Republican Brotherhood in the mid-nineteenth century, these norms can be tracked during the Irish War of Independence (see Regan 2013). Regarding themselves heirs to the previous republican activists, pursuing similar goals, and recruiting from a similar pool of recruits, republican armed groups during 1970 s were likely to be constrained by a pathdependent institutional culture of focusing on combatants who represented the imperial power and by an ethos of non-sectarianism (Hughes 2013). Republican paramilitary leaders also had to take into account the views of their key constituency, which was averse to the use of violence for political ends at the start of the conflict. In a 1968 survey, only 13 percent of Catholic respondents agreed with a statement that it "would be right to take any measures necessary in order to end partition and bring Ulster into the Republic" (Rose 1971: 480-483).

With roots in the Orange Order, loyalism and unionism emerged as anti-Catholic colonist ideologies in seventeenth century Ireland (Brewer and Higgins 1998). They crystallized defensive attitudes that characterized settler identity among Protestant communities in the northern plantations of Ireland. Subsequently, they became founding principles for the partition of Ireland in 1921 and the creation of a new province of Northern Ireland within the UK (Brewer and Higgins 1998, 87; Lustick 1993). Having inherited these beliefs, loyalist paramilitary ideological discourse from 1960 on emphasized that "Ulster Loyalists live in a state of eternal siege" and that Northern Ireland Protestants regard Catholics as an ideological foe - "uncommitted citizens, intent on the destruction of Northern Ireland" (New Ulster Political Research Group 1987). In the same 1968 survey (Rose 1971: 480-483), $5^{1}$ percent of Protestant respondents agreed with the statement that it "would be right to take any measures 
necessary in order to keep Northern Ireland a Protestant country." Against this background, it is likely that the loyalist paramilitaries felt less restrained than republicans in their targeting strategy.

\section{Recruitment Patterns}

The cornerstone of the loyalist ideology - defending the Union with Britain - allowed its supporters to join not only the paramilitaries but also the local state forces. This possibly resulted in qualitatively different groups of recruits. Bruce argues that loyalist paramilitaries recruited from a less competent pool than republicans because capable Protestants joined the local RUC and UDR forces (Bruce 1997, 59). However, it may not have been - or may not have been only - the question of competence: our statistical analysis shows that the experience of members does not explain armed groups' targeting patterns once ideology is accounted for. Building on Bruce's reasoning as well as our evidence, it seems more likely that loyalist paramilitary groups attracted recruits who were more radical and sectarian in their ideological stances.

The specific type of recruitment and socialization many republican recruits ended up undergoing also probably had a profound impact on their targeting patterns. Given its treatment of the republican movement as an insurgency, the British state applied internment without trial selectively: during the use of internment from August 1971 until December 1975, out of 1,981 people detained 1,874 were Catholic/republican (CAIN 2015). In its publications in the early 1970s, PIRA concentrated its ideological socialization effort on two major elements: non-sectarianism and appealing to the key role of Irish Protestants in the United Irishmen (the foundational movement of Irish republicanism), and armed struggle against British colonialism (Hughes 2013). The 
principles of inclusiveness were deliberated upon, developed and passed through the republican networks created by internment. Thus, ironically, the policy of internment facilitated the process of socialization and ideological indoctrination for the PIRA and other republicans, the specific mode of which enabled the latter to contain civilian victimization. In contrast, despite their centrality, moderating loyalist leaders, such as the iconic leaders of UVF and UDA Gusty Spence and John McMichael, did not have the opportunity provided by the internment policy to reorient their groups in a more restrained and less sectarian ideological direction.

\section{State Collusion}

When ideological projects of the state and a paramilitary group overlap, collusion between them is a likely outcome (Staniland 2015). The affinity of loyalism with the ideological project and political stance of the British state - favoring the Union and viewing republicans as the adversary - implied a natural alliance. By now, there is a rich body of evidence that testifies to a deep collusion that emerged between loyalist paramilitary groups and the state security forces from early 1970s. The Nelson Case (1992) and others revealed that leading loyalist paramilitaries were working undercover as state agents (Stevens, 2005). According to official UK government enquiries, key security institutions in the state, in particular RUC Special Branch and the section of British Military Intelligence known as the Force Research Unit or Field Reconnaissance Unit (FRU), systematically colluded with the main loyalist armed group (UDA), providing it with secret intelligence information about republican activists, using the state undercover agents to manage targeting, and had a "culture" of illegality (Stevens 2003; 2005; Cory 2003; de Silva 2012; Police Ombudsman 2016). A UK Security Service report of 1985 assessed that $85 \%$ of the UDA's "intelligence" originated from sources 
within the security forces (de Silva 2012). RUC and UDR members were active within loyalist paramilitary units that conducted sectarian killings from early 1970s (see Cadwallader 2013, particularly on the "Glennane gang”).

It may be puzzling that despite having necessary information and opportunity to be more selective, and having guidance from competent employees of state security institutions, loyalist paramilitaries were not restrained in their violence against civilians. However, the support from the state forces as well as the initial superiority of loyalism's political position in Northern Ireland may have fostered a lack of restraint among loyalist paramilitary elites and recruits and failed to incentivize the refashioning of their ideology in a non-sectarian direction. ${ }^{\text {"l }}$ Their development of politically astute non-sectarian strategies was weak, instead making their groups more porous for infiltration by ultra-radicals.

Given the systematic nature of this collusion and the fact that states often contract out violence against civilians to militias (Raleigh 2012), could civilian victimization by loyalist armed groups also be a result of strategic outsourcing of violence by elements within the state to pro-government militias to achieve ideological and political ends? Modern military theories of insurgency and counterinsurgency see the local populations as pivotal elements in a strategic game between belligerents, and their allegiance or compliance are seen by some as usually determined by force (Kilcullen 2010; Lyall 2009). The "outsourcing" of civilian victimization to loyalist groups could be seen as the state's attempt to raise the costs of Catholics' support for insurgency and to achieve allegiance or compliance. There remains a paucity of systematic evidence, and these are ultimately questions for future research. 


\section{Alternative Explanation: Political and strategic choices, not ideology}

It might be objected that civilian victimization in the Northern Ireland conflict reflected the strategic choices of warring factions, not their ideologies. The thesis holds that civilian victimization aims to either raise the costs to civilians of supporting an armed group or to pressure the enemy into concessions by victimizing its population base. Fay argues that loyalist targeting of Catholics fits this "strategic logic" of counterinsurgency - pressuring republicans by victimizing Catholic civilians (Fay 1999, 94, 135). Stanton sees restraint, too, in instrumental rather than ideological terms: governments or insurgents avoid targeting civilians to win domestic or international support by demonstrating respect for international humanitarian law (Stanton 2009). Despite its omission - domestic or international support can be secured by governments and paramilitaries from sources that do not care for international humanitarian law (Salehyan et al. 2014) - it can be argued that the armed groups were more or less restrained mainly for instrumental reasons.

The evidence we have does not support this view. First, with the amount of information available to loyalists through state collusion, it would have been more logical to target republican paramilitaries directly. Second, republican paramilitaries targeted mostly combatants despite the facts that these were high risk, costly activities - at the minimum, the combatant targets can be armed (even when off-duty) and trained and, therefore, easily reciprocate by violence. If they were operating within the strategic calculus outlined above, then republican paramilitaries should have targeted 
mostly civilians, as they were much easier targets and that could have been a tangible strategic way of pressuring loyalists and the British government. Republicans were denounced by the British state and loyalists as terrorists in any event, and they received support from different international sources, so theoretically they had little to lose in the propaganda war, except in so far as such tactics would be self-undermining from their own ideological position.

\section{CONCLUSION AND IMPLICATIONS}

In this article, we have theorized and empirically examined the role of group ideology in explaining patterns of civilian victimization across belligerents. Employing an original micro-level dataset that allows sub-national and armed group-level statistical analysis, we found that the ideologies of armed groups in Northern Ireland's civil war consistently predicted their targeting patterns, in line with some previous qualitative accounts on armed blocs or specific paramilitary organizations (O’Duffy 1995; O’Leary 2005; White 1997). These results survive a battery of robustness checks. We offer preliminary evidence that suggests that the path dependencies in norms, the recruitment patterns, and the relations with the state forces can explain why group ideology was associated with targeting patterns.

Furthermore, our results lend empirical support to our conjecture that, in some cases, other organizational characteristics - such as capability, external support, and discipline - may be endogenous to the warring factions' ideologies. While we do not claim that this travels across all cases of civil wars, we do take it as an important signal that ideology should be treated much more seriously than it has been in mainstream 
civil war literature in political science and economics. Ignoring group ideology or downplaying its role risks creating a dangerously incomplete or skewed account.

Naturally, our findings may have limitations. First, based on our logic that killings are probably the most critical indicators of victimization, following Downes and Balcells, we operationalized civilian victimization in terms of fatalities (Downes 2006 and Balcells 2010). Our model may not explain - or at least not as well - situations where the repertoire of victimization includes a wider array of violent acts, although, all else being equal, we do not see why ideology should not matter in such instances. Second, like Humphreys and Weinstein (2006), we examined our hypotheses based on evidence from one civil war, which may have had features that made ideology a prominent factor in civilian victimization, such as the fact that the conflict we study took place in a developed industrialized democracy and exhibited typical characteristics of ethnic civil wars. These features of the Northern Ireland conflict possibly may limit the realm within which our story on the role of ideology holds. Also, our location variables are measured on constituency rather than a lower level, such as wards. Unfortunately, such fine-grained systematic data that stretch back to the beginning of the Northern Ireland conflict is very difficult to assemble, especially given several sub-national boundary changes that took place during the conflict. ${ }^{12}$ Finally, our results may not generalize to cases of higher-intensity civil wars.

Nevertheless, the gist of this article's findings implies significant re-conceptualization is required in the efforts to understand and resolve civil wars and we suggest important avenues for future research. First, we suggest that prevention of civilian victimization requires a closer look at ideological frameworks of warring factions in a civil war. The impact of ideology on civilian victimization can be part of a broader, global pattern. If 
ideologies can spread through diffusion, their effect on violence against civilians may also travel across borders. This is all the more critical because the globalization of technology and information flows can enhance the diffusion of ideologies, regardless of their normative stances, as demonstrated by the Islamic State's astute propaganda machine. While the principles displayed by Kurdish forces in Syria can serve as a blueprint for some armed groups in other conflicts, Isil's al-Qaeda-inspired approach, including the principles it has displayed in Deir Al Zor and elsewhere, can undoubtedly further inspire and be emulated by others. Second, the repertoire of violence used may be a strong factor in the post-conflict political legitimacy of belligerents. Sinn Féin has had electoral success, whereas loyalist paramilitary efforts to engage in democratic politics have been very modest. This suggests that belligerents' ideologies and the practice of civilian victimization can undermine the legitimacy required to make the transition to party politics after conflict ends. 


\section{REFERENCES}

Asal, Victor, and R. Karl Rethemeyer. 2008. "Dilettantes, ideologues, and the weak: Terrorists who don't kill." Conflict Management and Peace Science 25 (3): 244263.

Asal, Victor, Mitchell Brown, and Marcus Schulzke. 2015."Kill Them All—Old and Young, Girls and Women and Little Children.” Political Science Research and Methods: 1-19.

Azam, Jean-Paul, and Anke Hoeffler. 2002."Violence against civilians in civil wars: looting or terror?" Journal of Peace Research 39(4):461-485.

Balcells, Laia. 2011."Continuation of politics by two means: Direct and indirect violence in civil war." Journal of Conflict Resolution 55(3):397-422.

Balcells, Laia. 2010."Rivalry and Revenge: Violence against Civilians in Conventional Civil Wars." International Studies Quarterly 54(2):291-313.

Blattman, Christopher, and Edward Miguel. 2010."Civil war." Journal of Economic Literature: 3-57.

Bloomfield, Sir Kenneth KCB. 1998. We Will Remember Them. Report of the Northern Ireland Victim's Commissioner.

http://cain.ulst.ac.uk/issues/victims/docs/bloomfieldg8.pdf

Brewer, John, and Gareth Higgins. 1998. Anti-Catholicism in Northern Ireland, 160o1998. Macmillan.

Bruce, Steve. 1997. "Victim selection in ethnic conflict: Motives and attitudes in Irish republicanism.” Terrorism and Political Violence 9(1):56-71. 
Buhaug, Halvard, Lars-Erik Cederman, and Jan Ketil Rød. 20o8."Disaggregating ethnonationalist civil wars." International Organization 62(3):531-551.

Cadwallader, Anne. 2013. Lethal Allies: British Collusion in Ireland. Mercier Press.

CAIN. 2015. Conflict Archive on the InterNet. University of Ulster. Accessed April 14, 2015: http://cain.ulst.ac.uk/othelem/chron.htm.

Cederman, Lars-Erik, and Kristian Skrede Gleditsch. 2009. "Introduction to Special Issue on Disaggregating Civil War." Journal of Conflict Resolution 53:487-495.

Collier, Paul, and Anke Hoeffler. 1998."On economic causes of civil war." Oxford Economic Papers 50(4):563-573.

Cory, Peter. 2003. Cory Collusion Inquiry Reports. Accessed April 12, 2015 at: http://cain.ulst.ac.uk/issues/collusion/

Downes, Alexander. 2006."Desperate times, desperate measures." International Security 30(4):152-195.

Drake, Charles JM. 1998."The role of ideology in terrorists' target selection." Terrorism and Political Violence 10 (2): 53-85.

Fay, Marie-Therese. 1999. Northern Ireland's troubles. Pluto Press.

Fearon, James, and David Laitin. 2003."Ethnicity, insurgency, and civil war." American Political Science Review 97(1):75-90.

Fjelde, Hanne, and Lisa Hultman. 2014. "Weakening the Enemy: A Disaggregated Study of Violence against Civilians in Africa." Journal of Conflict Resolution.

Freeden, Michael. 2003. Ideology. Oxford: Oxford University Press.

Gulf News. 2014. "Isil beheads, crucifies in push for Syria's east.” August 11.

Hughes, James. 2013. "State violence in the origins of nationalism" In: Hall, John A. and Malesevic, Sinisa, (eds.) Nationalism and War. Cambridge University Press. 
Hultman, Lisa. 2012. "COIN and civilian collaterals: patterns of violence in Afghanistan, 2004-2009." Small Wars E Insurgencies 23(2):245-263.

HRW 2015. World Report 2015: Syria. Human Rights Watch. Available at https://www.hrw.org/world-report/2015/country-chapters/syria

ICRC. 2015. Third Geneva Convention, Article 4(A)(4). International Committee of the Red Cross.

Jost, John, Christopher Federico, and Jaime Napier. 2009."Political ideology." Annual Review of Psychology 6o: 307-337.

Juergensmeyer, Mark. 2017. Terror in the Mind of God. University of California Press.

Kalyvas, Stathis. 2006. The Logic of Violence in Civil War. Cambridge University Press.

Kalyvas, Stathis, and Laia Balcells. 2010."International system and technologies of rebellion." American Political Science Review 104(3):415-429.

Kilcullen, David. Counterinsurgency. Oxford: Oxford University Press, 2010.

Lawrence, T.E. 1920. “The Evolution of a Revolt”. Army Quarterly and Defence Journal: 1-22.

Loyle, Cyanne, Christopher Sullivan, and Christian Davenport.2014."The Northern Ireland Research Initiative." Conflict Management and Peace Science 31(1):94106.

Lustick, Ian.1993. Unsettled States, Disputed Lands. Cornell University Press.

Machiavelli, Niccolò. 2005. The Prince. Oxford: Oxford University Press.

Mansfield, Edward and Snyder, Jack. 1995. "Democratization and the Danger of War". International Security $20(1): 5-38$.

Mao, Tse-Tung. 1961. On Guerrilla Warfare. University of Illinois Press. 
McKeown, Michael. 2009. Post-Mortem: An examination of the patterns of politically associated violence in Northern Ireland. Available at: http://cain.ulst.ac.uk/victims/mckeown/index.html

McKittrick, David, Seamus Kelters, Brian Feeney, Chris Thornton, and David McVea. 2001. Lost Lives. Random House.

New Ulster Political Research Group. 1987."Common sense: Northern Ireland—an agreed process." Belfast: UPRG. Last accessed 25 February 2016: http://cain.ulst.ac.uk/issues/politics/docs/commonsense.htm.

Police Ombudsman of Northern Ireland. 2016. Statutory Report. Available at https://www.policeombudsman.org/

O'Leary, Brendan. 2005."Mission Accomplished? Looking Back at the IRA," Field Day Review 1:217-45.

O'Leary, Brendan, and John McGarry. 1993. The Politics of Antagonism: Understanding Northern Ireland. London:Athlone Press.

O'Duffy, Brendan. 1995. "Violence in Northern Ireland 1969-1994: Sectarian or ethno-national?" Ethnic and Racial Studies 18(4):740-772.

Operation Banner (2006). An Analysis of Military Operations in Northern Ireland. Prepared under the direction of the Chief of the General Staff. https://www.vilaweb.cat/media/attach/vwedts/docs/op banner_analysis releas ed.pdf

Oppenheim, Ben, Abbey Steele, Juan Vargas, and Michael Weintraub. 2015."True Believers, Deserters, and Traitors." Journal of Conflict Resolution.

Petersen, Roger. 2001.Resistance and Rebellion. Cambridge University Press.

Raleigh, Clionadh. 2012."Violence against civilians: A disaggregated analysis." International Interactions 38 (4):462-481. 
Regan, John. 2013. Myth and the Irish State. Irish Academic Press.

Reuters. 2014. “Islamic State executed 70o people from Syrian tribe.” August 16.

Rose, Richard. 1971. Governing without Consensus: An Irish Perspective. Boston, MA: Beacon Press.

Salehyan, Idean, David Siroky, and Reed Wood. 2014."External rebel sponsorship and civilian abuse." International Organization 68 (3): 633-661.

Sánchez-Cuenca, Ignacio, and Luis De la Calle. 2009."Domestic terrorism." Annual Review of Political Science 12:31-49.

Sanín, Gutiérrez Francisco, and Elisabeth Jean Wood. 2014. "Ideology in civil war: Instrumental adoption and beyond." Journal of Peace Research 51(2):213-226.

de Silva, Desmond. (2012). The Report of the Patrick Finucane Review. London: Stationery Office.

Snyder, Jack. 200o. From Voting to Violence: Democratization and Nationalist Conflict. W.W.Norton.

Staniland, Paul. 2015. "Militias, Ideology, and the State." Journal of Conflict Resolution. Stanton, Jessica. 2009. Strategies of violence and restraint in civil war. $\mathrm{PhD}$ dissertation: Columbia University.

Stanton, Jessica A. 2015. "Regulating militias: Governments, militias, and civilian targeting in civil war." Journal of Conflict Resolution 59(5):899-923.

Stevens, John. 2003. Stevens Enquiry. Accessed April 12, 2015 at: http://cain.ulst.ac.uk/issues/collusion/stevens3/stevens3summary.htm

Stevens, John. 2005. Not for the Faint-Hearted. London: Weidenfield \& Nicholson.

Sutton, Malcolm. 2001. An Index of Deaths from the Conflict in Ireland, 1969-1993. Beyond the Pale Publications. 
Thaler, Kai M. 2012. "Ideology and Violence in Civil Wars: Theory and Evidence from Mozambique and Angola." Civil Wars 14(4):546-567.

Tilly, Charles. 2004."Terror, terrorism, terrorists." Sociological Theory 22(1):5-13.

Todd, Jennifer. 1987."Two traditions in unionist political culture." Irish Political Studies 2(1):1-26.

Ugarriza, Juan, and Matthew Craig. 2013. "The relevance of ideology to contemporary armed conflicts." Journal of Conflict Resolution 57 (3): 445-477.

Valentino, Benjamin, Paul Huth, and Dylan Balch-Lindsay. 2004. "“Draining the sea”: mass killing and guerrilla warfare." International Organization 58(2): 375-407.

Weinstein, Jeremy. 2007. Inside Rebellion. Cambridge University Press.

White, Robert. 1997. The Irish Republican Army: An assessment of sectarianism, Terrorism and Political Violence 9(1):20-55.

Wood, Elizabeth and Toppelberg, Nathaniel.2017."The persistence of sexual assault within the US military." Journal of Peace Research 54(5):620-633.

Wood, Reed M. 2010. "Rebel capability and strategic violence against civilians." Journal of Peace Research 47(5):601-614.

Wood, Reed M. 2014. "From Loss to Looting? Battlefield Costs and Rebel Incentives for Violence."International Organization 68(4):979-999.

Wooldridge, Jeffrey M. 2010. Econometric Analysis of Cross Section and Panel Data. MIT Press.

Zhou, Xiao-Hua, Donna McClish, and Nancy Obuchowski. 20o9. Statistical Methods in Diagnostic Medicine. John Wiley \& Sons. 


\section{TABLES}

Table 1. Multivariate Results with Clustering by Year, All Civilians

\begin{tabular}{|c|c|c|c|c|c|c|}
\hline $\begin{array}{l}\text { Model: } \\
\text { Type of Violence: } \\
\text { Dependent Variable: }\end{array}$ & $\begin{array}{c}1 \\
\text { All } \\
\text { Civilian } \\
\end{array}$ & $\begin{array}{c}2 \\
\text { All } \\
\text { Civilian } \\
\end{array}$ & $\begin{array}{c}3 \\
\text { All } \\
\text { Civilian } \\
\end{array}$ & $\begin{array}{c}4 \\
\text { Volitional } \\
\text { Civilian } \\
\end{array}$ & $\begin{array}{c}5 \\
\text { Volitional } \\
\text { Civilian } \\
\end{array}$ & $\begin{array}{c}6 \\
\text { Volitional } \\
\text { Civilian } \\
\end{array}$ \\
\hline \multicolumn{7}{|l|}{ Allegiances } \\
\hline Home & $\begin{array}{c}0.540 \\
(0.230)\end{array}$ & $\begin{array}{c}0.529 \\
(0.225)\end{array}$ & $\begin{array}{c}0.519 \\
(0.222)\end{array}$ & $\begin{array}{c}0.407 \\
(0.236)\end{array}$ & $\begin{array}{c}0.390 \\
(0.233)\end{array}$ & $\begin{array}{c}0.387 \\
(0.232)\end{array}$ \\
\hline \multicolumn{7}{|l|}{ Cleavages } \\
\hline Co-ethnic Area & $\begin{array}{c}0.476^{* * *} \\
(0.107)\end{array}$ & $\begin{array}{c}0.458^{* * *} \\
(0.105)\end{array}$ & $\begin{array}{c}0.455^{* * *} \\
(0.105)\end{array}$ & $\begin{array}{c}0.434^{* * *} \\
(0.136)\end{array}$ & $\begin{array}{c}0.413^{* * *} \\
(0.131)\end{array}$ & $\begin{array}{c}0.413^{* * *} \\
(0.131)\end{array}$ \\
\hline \multicolumn{7}{|l|}{ Control } \\
\hline Dominance & $\begin{array}{c}1.027 \\
(0.031)\end{array}$ & $\begin{array}{c}1.028 \\
(0.031)\end{array}$ & $\begin{array}{l}1.030 \\
(0.031)\end{array}$ & $\begin{array}{c}1.057 \\
(0.039)\end{array}$ & $\begin{array}{c}1.060 \\
(0.040)\end{array}$ & $\begin{array}{l}1.060 \\
(0.041)\end{array}$ \\
\hline \multicolumn{7}{|l|}{ Capabilities } \\
\hline Size & $\begin{array}{c}1.173 \\
(0.207)\end{array}$ & $\begin{array}{c}0.547^{* * *} \\
(0.116)\end{array}$ & $\begin{array}{c}0.812 \\
(0.139)\end{array}$ & $\begin{array}{c}1.358 \\
(0.302)\end{array}$ & $\begin{array}{c}0.585^{* * *} \\
(0.115)\end{array}$ & $\begin{array}{c}0.942 \\
(0.136)\end{array}$ \\
\hline Experience & $\begin{array}{c}3.270^{* * *} \\
(1.469)\end{array}$ & $\begin{array}{c}0.803 \\
(0.545)\end{array}$ & $\begin{array}{c}0.849 \\
(0.416)\end{array}$ & $\begin{array}{l}4.025^{*} \\
(2.992)\end{array}$ & $\begin{array}{c}0.729 \\
(0.368)\end{array}$ & $\begin{array}{c}1.167 \\
(0.476)\end{array}$ \\
\hline \multicolumn{7}{|l|}{ Resources } \\
\hline External Support & $\begin{array}{c}13.603^{* * *} \\
(10.634)\end{array}$ & $\begin{array}{c}6.396 \\
(7.900)\end{array}$ & $\begin{array}{c}2.705 \\
(2.819)\end{array}$ & $\begin{array}{l}9.119^{* *} \\
(8.223)\end{array}$ & $\begin{array}{c}1.484 \\
(1.078)\end{array}$ & $\begin{array}{c}1.118 \\
(0.733)\end{array}$ \\
\hline Crime Rents & $\begin{array}{c}0.463^{* *} \\
(0.173)\end{array}$ & $\begin{array}{c}0.709 \\
(0.437)\end{array}$ & $\begin{array}{c}0.566 \\
(0.267)\end{array}$ & $\begin{array}{c}0.603 \\
(0.252)\end{array}$ & $\begin{array}{c}1.588 \\
(0.590)\end{array}$ & $\begin{array}{c}0.870 \\
(0.250)\end{array}$ \\
\hline \multicolumn{7}{|l|}{ Organization } \\
\hline Coherent Structure & $\begin{array}{c}0.563 \\
(0.252)\end{array}$ & $\begin{array}{c}0.575 \\
(0.384)\end{array}$ & $\begin{array}{c}0.587 \\
(0.327)\end{array}$ & $\begin{array}{c}0.814 \\
(0.428)\end{array}$ & $\begin{array}{c}1.394 \\
(0.513)\end{array}$ & $\begin{array}{c}1.015 \\
(0.339)\end{array}$ \\
\hline Discipline & $\begin{array}{c}0.056^{* * *} \\
(0.016)\end{array}$ & $\begin{array}{c}1.180 \\
(0.874)\end{array}$ & $\begin{array}{c}0.865 \\
(0.398)\end{array}$ & $\begin{array}{c}0.030^{* * *} \\
(0.012)\end{array}$ & $\begin{array}{c}1.412 \\
(0.904)\end{array}$ & $\begin{array}{c}0.638 \\
(0.302)\end{array}$ \\
\hline \multicolumn{7}{|l|}{ Ideology } \\
\hline Republicanism & & $\begin{array}{c}0.069^{* * *} \\
(0.053)\end{array}$ & & & $\begin{array}{c}0.032^{* * *} \\
(0.021)\end{array}$ & \\
\hline Loyalism & & & $\begin{array}{c}13.588^{* * *} \\
(7.003)\end{array}$ & & & $\begin{array}{c}18.709^{* * *} \\
(9.278)\end{array}$ \\
\hline Constant & $\begin{array}{c}3.201 \\
(5.367)\end{array}$ & $\begin{array}{l}927.119^{* * *} \\
(2,055 \cdot 438)\end{array}$ & $\begin{array}{l}25.599^{*} \\
(48.797)\end{array}$ & $\begin{array}{c}0.258 \\
(0.467)\end{array}$ & $\begin{array}{c}57.889^{* * *} \\
(80.745)\end{array}$ & $\begin{array}{c}1.110 \\
(1.243)\end{array}$ \\
\hline Observations & 3,340 & 3,340 & 3,340 & 2,951 & 2,951 & 2,951 \\
\hline$\%$ Correctly Predicted & 71.19 & 71.17 & 71.19 & 77.11 & 77.14 & 77.14 \\
\hline AUROC & 0.75 & 0.75 & 0.75 & 0.80 & 0.80 & 0.80 \\
\hline
\end{tabular}

Note: Results of logistic regression. Reported in cells are odds ratios with robust standard errors in parentheses clustered by year. ${ }^{* * *},{ }^{* *}$, and ${ }^{*}$ are for $\mathrm{p}<0.01, \mathrm{p}<0.05$, and $\mathrm{p}<0.1$. 
Table 2. Multivariate Results with Clustering by Year, Civilians by Religion

\begin{tabular}{|c|c|c|c|c|c|c|c|c|}
\hline $\begin{array}{l}\text { Model: } \\
\text { Type of Violence: } \\
\text { Dependent Variable: }\end{array}$ & $\begin{array}{c}1 \\
\text { All } \\
\text { Catholic } \\
\text { Civilian }\end{array}$ & $\begin{array}{c}2 \\
\text { All } \\
\text { Protestant } \\
\text { Civilian }\end{array}$ & $\begin{array}{c}3 \\
\text { All } \\
\text { Catholic } \\
\text { Civilian }\end{array}$ & $\begin{array}{c}4 \\
\text { All } \\
\text { Protestant } \\
\text { Civilian }\end{array}$ & $\begin{array}{l}5 \\
\text { Volitional } \\
\text { Catholic } \\
\text { Civilian }\end{array}$ & $\begin{array}{c}6 \\
\text { Volitional } \\
\text { Protestant } \\
\text { Civilian }\end{array}$ & $\begin{array}{l}\quad 7 \\
\text { Volitional } \\
\text { Catholic } \\
\text { Civilian }\end{array}$ & $\begin{array}{c}8 \\
\text { Volitional } \\
\text { Protestant } \\
\text { Civilian }\end{array}$ \\
\hline \multicolumn{9}{|l|}{ Allegiances } \\
\hline Home & $\begin{array}{c}0.869 \\
(0.366)\end{array}$ & $\begin{array}{c}0.803 \\
(0.453)\end{array}$ & $\begin{array}{c}0.853 \\
(0.362)\end{array}$ & $\begin{array}{l}0.808 \\
(0.457)\end{array}$ & $\begin{array}{c}0.491 \\
(0.307)\end{array}$ & $\begin{array}{c}1.002 \\
(0.704)\end{array}$ & $\begin{array}{c}0.485 \\
(0.306)\end{array}$ & $\begin{array}{c}1.005 \\
(0.705)\end{array}$ \\
\hline \multicolumn{9}{|l|}{ Cleavages } \\
\hline Co-ethnic Area & $\begin{array}{l}0.621^{*} \\
(0.151)\end{array}$ & $\begin{array}{c}1.693 \\
(0.678)\end{array}$ & $\begin{array}{l}0.620^{*} \\
(0.151)\end{array}$ & $\begin{array}{l}1.680 \\
(0.672)\end{array}$ & $\begin{array}{c}0.658 \\
(0.174)\end{array}$ & $\begin{array}{c}1.524 \\
(0.634)\end{array}$ & $\begin{array}{c}0.659 \\
(0.174)\end{array}$ & $\begin{array}{c}1.518 \\
(0.631)\end{array}$ \\
\hline \multicolumn{9}{|l|}{ Control } \\
\hline Dominance & $\begin{array}{c}0.988 \\
(0.034)\end{array}$ & $\begin{array}{c}1.030 \\
(0.044)\end{array}$ & $\begin{array}{c}0.989 \\
(0.034)\end{array}$ & $\begin{array}{c}1.029 \\
(0.044)\end{array}$ & $\begin{array}{c}1.021 \\
(0.045)\end{array}$ & $\begin{array}{c}1.029 \\
(0.052)\end{array}$ & $\begin{array}{c}1.021 \\
(0.045)\end{array}$ & $\begin{array}{c}1.028 \\
(0.052)\end{array}$ \\
\hline \multicolumn{9}{|l|}{ Capabilities } \\
\hline Size & $\begin{array}{l}0.784 \\
(0.117)\end{array}$ & $\begin{array}{l}0.731^{*} \\
(0.129)\end{array}$ & $\begin{array}{l}1.206 \\
(0.138)\end{array}$ & $\begin{array}{c}0.600^{* * *} \\
(0.106)\end{array}$ & $\begin{array}{l}0.736^{*} \\
(0.123)\end{array}$ & $\begin{array}{c}0.808 \\
(0.147)\end{array}$ & $\begin{array}{c}1.178 \\
(0.150)\end{array}$ & $\begin{array}{l}0.681^{* *} \\
(0.126)\end{array}$ \\
\hline Experience & $\begin{array}{l}1.295 \\
(0.530)\end{array}$ & $\begin{array}{c}0.907 \\
(0.488)\end{array}$ & $\begin{array}{c}1.455 \\
(0.570)\end{array}$ & $\begin{array}{c}0.884 \\
(0.545)\end{array}$ & $\begin{array}{c}1.714 \\
(0.708)\end{array}$ & $\begin{array}{l}0.871 \\
(0.511)\end{array}$ & $\begin{array}{l}2.396^{* *} \\
(1.046)\end{array}$ & $\begin{array}{c}0.810 \\
(0.497)\end{array}$ \\
\hline \multicolumn{9}{|l|}{ Resources } \\
\hline External Support & $\begin{array}{l}6.814^{* *} \\
(5.624)\end{array}$ & $\begin{array}{c}0.891 \\
(0.772)\end{array}$ & $\begin{array}{c}2.917 \\
(2.173)\end{array}$ & $\begin{array}{c}1.092 \\
(1.068)\end{array}$ & $\begin{array}{l}5.213^{* *} \\
(4.180)\end{array}$ & $\begin{array}{c}0.484 \\
(0.423)\end{array}$ & $\begin{array}{l}3.446 \\
(3.035)\end{array}$ & $\begin{array}{c}0.543 \\
(0.507)\end{array}$ \\
\hline Crime Rents & $\begin{array}{c}0.582 \\
(0.205)\end{array}$ & $\begin{array}{l}1.024 \\
(0.375)\end{array}$ & $\begin{array}{c}0.467^{* * *} \\
(0.130)\end{array}$ & $\begin{array}{c}1.118 \\
(0.450)\end{array}$ & $\begin{array}{c}0.748 \\
(0.290)\end{array}$ & $\begin{array}{c}1.356 \\
(0.529)\end{array}$ & $\begin{array}{c}0.430^{* *} \\
(0.161)\end{array}$ & $\begin{array}{c}1.599 \\
(0.608)\end{array}$ \\
\hline \multicolumn{9}{|l|}{ Organization } \\
\hline $\begin{array}{l}\text { Coherent } \\
\text { Structure }\end{array}$ & $0.489^{*}$ & 1.046 & $0.508^{* *}$ & 1.018 & 0.565 & 1.738 & $0.429^{* *}$ & 1.854 \\
\hline & (o.194) & $(0.445)$ & $(0.166)$ & $(0.494)$ & $(0.227)$ & $(0.716)$ & $(0.181)$ & (o.788) \\
\hline Discipline & $\begin{array}{c}0.556 \\
(0.238)\end{array}$ & $\begin{array}{c}1.657 \\
(0.699)\end{array}$ & $\begin{array}{c}0.352^{* * *} \\
(0.131)\end{array}$ & $\begin{array}{c}2.494^{* *} \\
(0.951)\end{array}$ & $\begin{array}{l}0.589 \\
(0.312)\end{array}$ & $\begin{array}{l}1.180 \\
(0.463)\end{array}$ & $\begin{array}{c}0.287^{* *} \\
(0.143)\end{array}$ & $\begin{array}{c}1.630 \\
(0.626)\end{array}$ \\
\hline \multicolumn{9}{|l|}{ Ideology } \\
\hline Republicanism & $\begin{array}{l}0.064^{* * *} \\
(0.029)\end{array}$ & $\begin{array}{c}2.839^{* *} \\
(1.393)\end{array}$ & & & $\begin{array}{c}0.033^{* * *} \\
(0.018)\end{array}$ & $\begin{array}{c}3.000^{* *} \\
(1.467)\end{array}$ & & \\
\hline Loyalism & & & $\begin{array}{c}12.745^{* * *} \\
(5.079)\end{array}$ & $\begin{array}{l}0.476 \\
(0.221)\end{array}$ & & & $\begin{array}{c}19.431^{* * *} \\
(9.885)\end{array}$ & $\begin{array}{l}0.418^{*} \\
(0.191)\end{array}$ \\
\hline Constant & $\begin{array}{l}24.694^{* *} \\
(36.479)\end{array}$ & $\begin{array}{c}1.107 \\
(1.403)\end{array}$ & $\begin{array}{l}0.518 \\
(0.569)\end{array}$ & $\begin{array}{l}5.286 \\
(7.121)\end{array}$ & $\begin{array}{l}7.964^{*} \\
(9.032)\end{array}$ & $\begin{array}{c}0.158 \\
(0.254)\end{array}$ & $\begin{array}{l}0.166^{*} \\
(0.172)\end{array}$ & $\begin{array}{c}0.596 \\
(0.984)\end{array}$ \\
\hline Observations & 3,225 & 3,204 & 3,225 & 3,204 & 2,892 & 2,871 & 2,892 & 2,871 \\
\hline $\begin{array}{ll}\% & \text { Correctly } \\
\text { Predicted } & \end{array}$ & 87.08 & 81.09 & 87.08 & 81.09 & 90.70 & 83.60 & 90.70 & 83.60 \\
\hline AUROC & 0.84 & 0.70 & 0.84 & 0.70 & 0.91 & 0.70 & 0.91 & 0.70 \\
\hline
\end{tabular}

Note: Results of logistic regression. Reported in cells are odds ratios with robust standard errors in parentheses clustered by year. ${ }^{* * *},{ }^{* *}$, and ${ }^{*}$ are for $\mathrm{p}<0.01, \mathrm{p}<0.05$, and $\mathrm{p}<0.1$. 
Table 3. Robustness Checks

\begin{tabular}{|c|c|c|c|c|c|c|c|}
\hline $\begin{array}{l}\text { Model: } \\
\text { Type of Violence: }\end{array}$ & Civilian2 & Civilian2 & $\begin{array}{c}3 \\
\text { All } \\
\text { Protestant } \\
\text { Civilian2 }\end{array}$ & $\begin{array}{c}4 \\
\text { All } \\
\text { Protestant } \\
\text { Civilian2 }\end{array}$ & Civilian & Civilian & Civilian \\
\hline \multicolumn{8}{|l|}{ Allegiances } \\
\hline Home & $\begin{array}{c}0.229^{* * *} \\
(0.107)\end{array}$ & $\begin{array}{c}0.225^{* * *} \\
(0.106)\end{array}$ & $\begin{array}{c}0.449^{* *} \\
(0.157)\end{array}$ & $\begin{array}{l}0.455^{* *} \\
(0.158)\end{array}$ & $\begin{array}{c}0.529 \\
(0.225)\end{array}$ & $\begin{array}{c}0.45^{\circ} \\
(0.250)\end{array}$ & $\begin{array}{c}0.449 \\
(0.249)\end{array}$ \\
\hline \multicolumn{8}{|l|}{ Cleavages } \\
\hline Co-ethnic Area & $\begin{array}{c}0.537^{* * *} \\
(0.117)\end{array}$ & $\begin{array}{c}0.535^{* * *} \\
(0.117)\end{array}$ & $\begin{array}{c}2.770^{* *} \\
(1.126)\end{array}$ & $\begin{array}{c}2.760^{* *} \\
(1.120)\end{array}$ & $\begin{array}{c}0.45^{* * *} \\
(0.105)\end{array}$ & $\begin{array}{c}0.638 \\
(0.236)\end{array}$ & $\begin{array}{c}0.637 \\
(0.235)\end{array}$ \\
\hline \multicolumn{8}{|l|}{ Control } \\
\hline Dominance & $\begin{array}{l}1.053^{*} \\
(0.030)\end{array}$ & $\begin{array}{l}1.054^{*} \\
(0.031)\end{array}$ & $\begin{array}{c}1.030 \\
(0.029)\end{array}$ & $\begin{array}{c}1.029 \\
(0.028)\end{array}$ & $\begin{array}{l}1.028 \\
(0.031)\end{array}$ & $\begin{array}{c}1.050 \\
(0.040)\end{array}$ & $\begin{array}{l}1.050 \\
(0.040)\end{array}$ \\
\hline \multicolumn{8}{|l|}{ Capabilities } \\
\hline Size & $\begin{array}{c}0.546^{* * *} \\
(0.115)\end{array}$ & $\begin{array}{l}0.761^{*} \\
(0.119)\end{array}$ & $\begin{array}{l}0.795 \\
(0.117)\end{array}$ & $\begin{array}{c}0.588^{* * *} \\
(0.069)\end{array}$ & $\begin{array}{c}0.547^{* * *} \\
(0.116)\end{array}$ & $\begin{array}{l}0.643^{* *} \\
(0.129)\end{array}$ & $\begin{array}{l}0.760 \\
(0.140)\end{array}$ \\
\hline Experience & $\begin{array}{c}0.476 \\
(0.301)\end{array}$ & $\begin{array}{l}0.500 \\
(0.235)\end{array}$ & $\begin{array}{c}0.490 \\
(0.224)\end{array}$ & $\begin{array}{c}0.471 \\
(0.247)\end{array}$ & $\begin{array}{c}0.803 \\
(0.545)\end{array}$ & $\begin{array}{l}2.216^{* *} \\
(0.837)\end{array}$ & $\begin{array}{l}2.079^{* *} \\
(0.759)\end{array}$ \\
\hline \multicolumn{8}{|l|}{ Resources } \\
\hline External Support & $\begin{array}{c}6.314^{*} \\
(6.968)\end{array}$ & $\begin{array}{c}3.091 \\
(3.100)\end{array}$ & $\begin{array}{c}0.710 \\
(0.630)\end{array}$ & $\begin{array}{c}1.116 \\
(1.053)\end{array}$ & $\begin{array}{l}6.396 \\
(7.900)\end{array}$ & $\begin{array}{c}19.406^{* * *} \\
(18.864)\end{array}$ & $\begin{array}{l}11.244^{* *} \\
(10.694)\end{array}$ \\
\hline Crime Rents & $\begin{array}{c}1.104 \\
(0.574)\end{array}$ & $\begin{array}{l}0.903 \\
(0.371)\end{array}$ & $\begin{array}{l}1.592 \\
(0.491)\end{array}$ & $\begin{array}{l}1.813^{*} \\
(0.623)\end{array}$ & $\begin{array}{c}0.709 \\
(0.437)\end{array}$ & $\begin{array}{l}0.393^{* *} \\
(0.182)\end{array}$ & $\begin{array}{c}0.380^{* *} \\
(0.171)\end{array}$ \\
\hline \multicolumn{8}{|l|}{ Organization } \\
\hline $\begin{array}{l}\text { Coherent } \\
\text { Structure }\end{array}$ & 0.607 & 0.610 & 1.080 & 1.029 & 0.575 & 0.401 & 0.429 \\
\hline & $(0.361)$ & $(0.323)$ & $(0.450)$ & $(0.462)$ & $(0.384)$ & $(0.229)$ & $(0.240)$ \\
\hline Discipline & $\begin{array}{c}2.629 \\
(1.952)\end{array}$ & $\begin{array}{c}2.027 \\
(0.987)\end{array}$ & $\begin{array}{c}4.248^{* * *} \\
(1.749)\end{array}$ & $\begin{array}{c}6.880^{* * *} \\
(2.510)\end{array}$ & $\begin{array}{l}1.180 \\
(0.874)\end{array}$ & $\begin{array}{c}0.327^{* * *} \\
(0.135)\end{array}$ & $\begin{array}{r}0.326^{* * *} \\
(0.123)\end{array}$ \\
\hline \multicolumn{8}{|l|}{ Ideology } \\
\hline Republicanism & $\begin{array}{l}0.103^{* * *} \\
(0.082)\end{array}$ & & $\begin{array}{c}5 \cdot 577^{* * *} \\
(2.922)\end{array}$ & & & $\begin{array}{c}0.328^{* * *} \\
(0.117)\end{array}$ & \\
\hline Loyalism & & $\begin{array}{c}9.215^{* * *} \\
(5.144)\end{array}$ & & $\begin{array}{c}0.244^{* * *} \\
(0.123)\end{array}$ & & & $\begin{array}{c}3.364^{* * *} \\
(1.129)\end{array}$ \\
\hline Unionism & & & & & $\begin{array}{c}14.505^{* * *} \\
(11.102)\end{array}$ & & \\
\hline Constant & $\begin{array}{c}157.762^{* *} \\
(313.149)\end{array}$ & $\begin{array}{c}7 \cdot 731 \\
(12.551)\end{array}$ & $\begin{array}{l}0.100^{*} \\
(0.122)\end{array}$ & $\begin{array}{c}1.252 \\
(1.284)\end{array}$ & $\begin{array}{l}63.919^{* *} \\
(132.795)\end{array}$ & $\begin{array}{l}77.104^{* *} \\
(161.565)\end{array}$ & $\begin{array}{c}15.428 \\
(28.975)\end{array}$ \\
\hline Observations & 3,340 & 3,340 & 3,225 & 3,225 & 3,340 & 1,939 & 1,939 \\
\hline $\begin{array}{ll}\% & \text { Correctly } \\
\text { Predicted } & \end{array}$ & $65 \cdot 72$ & 65.71 & 68.21 & 68.21 & 71.17 & 72.51 & 72.51 \\
\hline AUROC & 0.68 & 0.68 & 0.75 & 0.75 & 0.75 & 0.76 & 0.76 \\
\hline
\end{tabular}

Note: Results of logistic regression. Reported in cells are odds ratios with robust standard errors in parentheses clustered by year. ${ }^{* * *},{ }^{* *}$, and ${ }^{*}$ are for $\mathrm{p}<0.01, \mathrm{p}<0.05$, and $\mathrm{p}<0.1$. 


\section{FIGURES}

Figure 1. Casualties by Perpetrator Armed Blocs over Time

All Violence

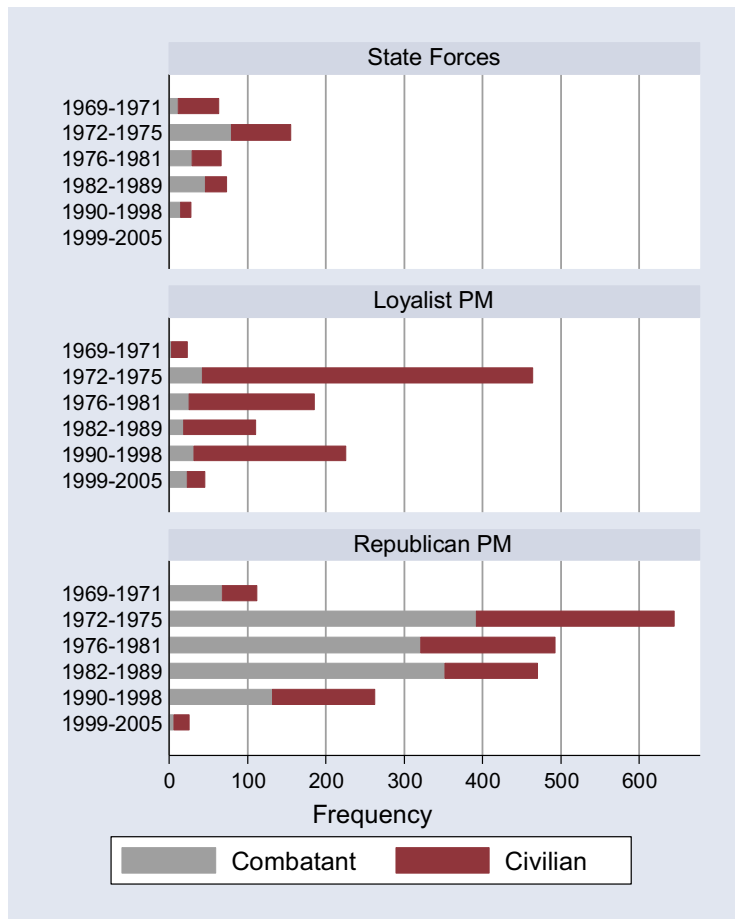

Volitional Violence

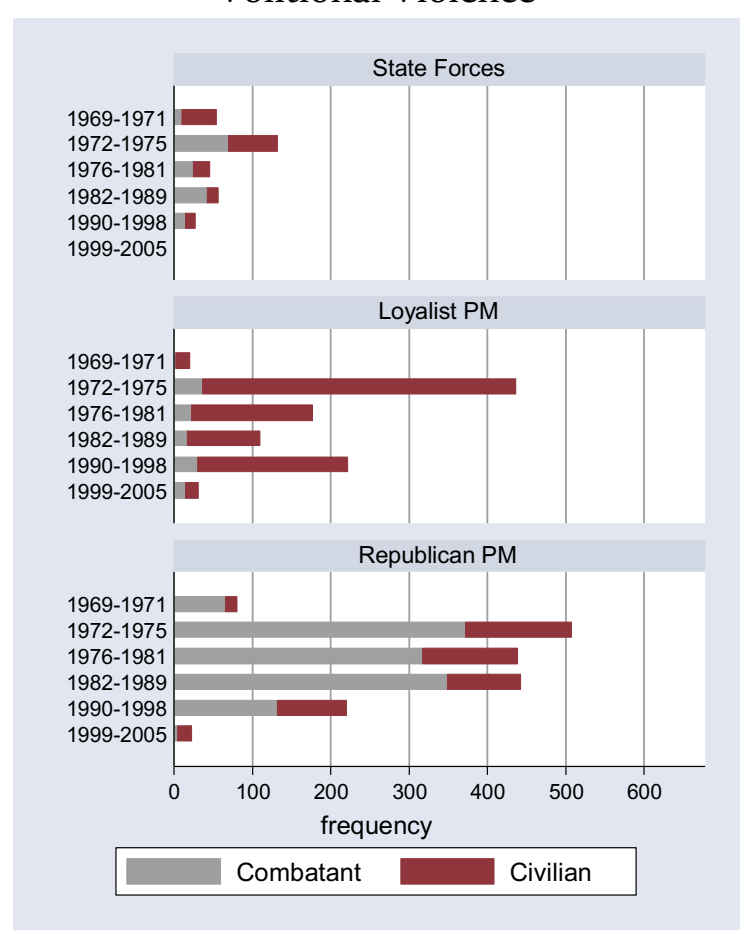


Figure 2. Civilian Casualties across Armed Blocs over Time, by Victims' Religion

All Violence

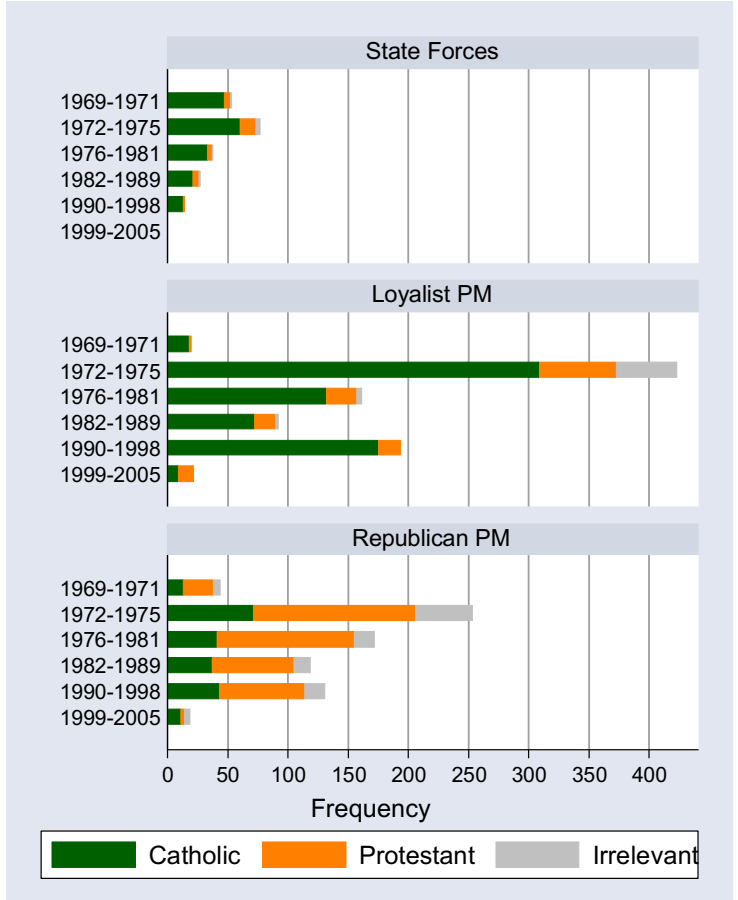

Volitional Violence

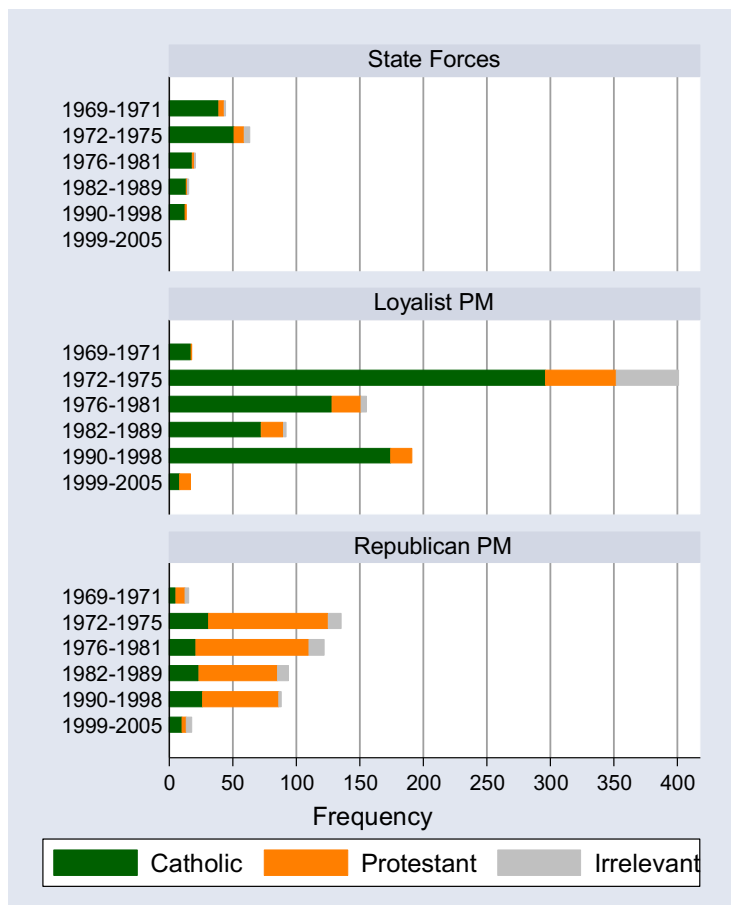


Figure 3. Civilian Casualties by Perpetrating Armed Blocs and Locations, by Victims' Religion

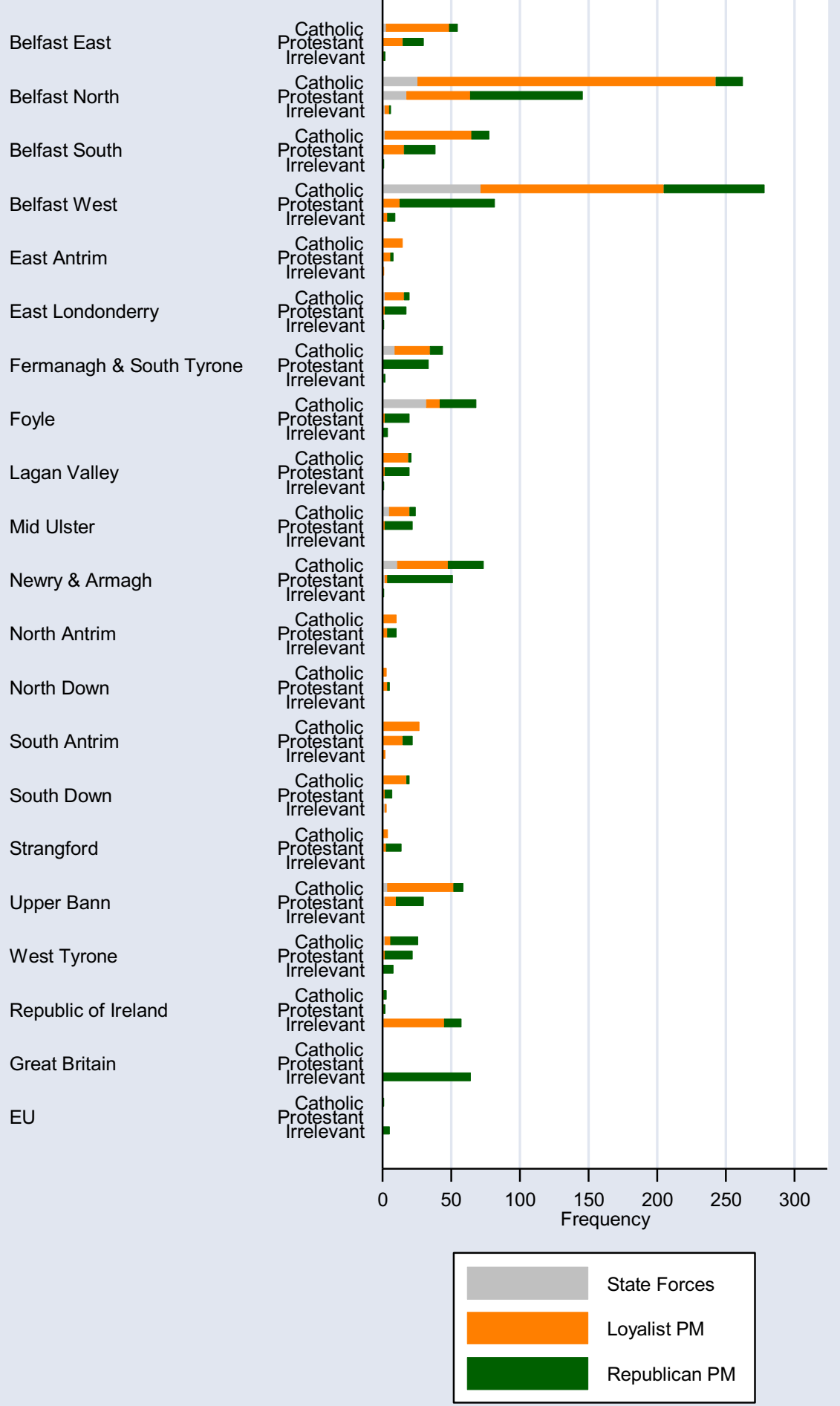


Figure 4. Context of Civilian Killings in Republican and Loyalist Paramilitary Violence, by Victims' Religion

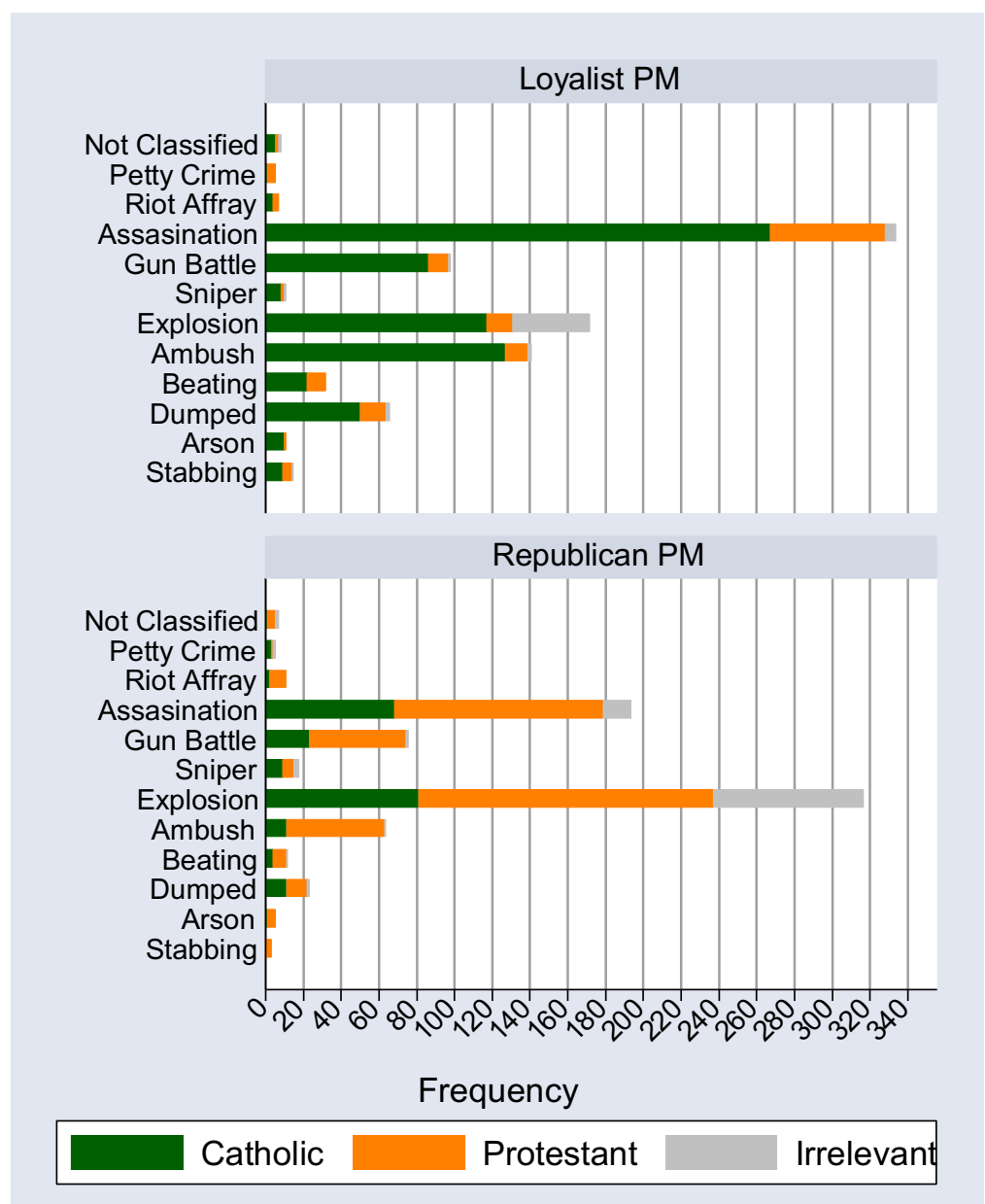

Source: Based on McKeown (2009) 


\section{ENDNOTES}

\footnotetext{
${ }^{1}$ For helpful summaries, see Hayes and McAllister 2001 and O’Leary and McGarry 1993.

${ }^{2}$ In robustness checks, we adopt a non-conservative definition.

${ }^{3}$ The strengths and weaknesses are different across the three sources. For example, McKeown (2009)
} presents structured data, Sutton (2001) gives dates of incidents, and McKittrick et al. (2001) provide a lot of useful qualitative information about victims. The weaknesses include inconsistencies or missing information on gender, victim's status, motivation behind killing, wrong coding of some combatants as non-combatants, and large number of fatalities with insufficiently specified responsible group.

${ }^{4}$ Formed in 1970, the UDR was merged with the Royal Irish Rangers to form the Royal Irish Regiment (RIR) in 1992.

${ }^{5}$ The choice of this sub-national level is dictated by the limitation in McKeown's 2009 dataset.

${ }^{6}$ In the Northern Ireland conflict, groups were invariably homogenous in their ethnic make-up, so an ethnic homogeneity variable would not add any value.

${ }^{7}$ In the case of Northern Ireland conflict the latter is more applicable as victimization was more likely to be clustered in time than space, possibly due to the relatively small size of the country and the relative segregation of different communities - groups were more likely to retaliate by violence in a different location but in the same time period.

${ }^{8}$ AUROC remains similar between models with and without ideology variables, suggesting that in the latter the significant variables were probably absorbing the effect of ideology.

${ }^{9}$ There was a fragmented landscape of armed groups in Northern Ireland which also reflects certain ideological differences when it comes to appropriate strategies and tactics. We can further disaggregate republicanism and loyalism by specific tenets associated with different armed groups within each camp. For the republican camp we find that, although all forms of republicanism are associated with a smaller likelihood of civilian victimization, this association is statistically significant for groups that espoused Irish republicanism and Irish republican socialism but not for groups that espoused far left views (e.g., Marxism-Leninism or Trotskyism). For the loyalist camp, we find that higher likelihood of civilian victimization is associated with Ulster loyalism per se but not necessarily with an ideological principle of Ulster self-determination. However, we stress that we should treat such disaggregation of ideological 
camps with additional caution because comparing a relatively limited number of armed groups in our statistical analysis can lead to biased estimates.

${ }^{10}$ The "murder triangle" refers to the area in Armagh and Tyrone which broadly corresponds with the activities of the "Glennane Gang" (for which see Cadwallader, 2013).

${ }^{11}$ On the link between impunity and socialization, see Wood and Toppelberg (2017).

${ }^{12}$ The efforts of Loyle et al. 2014 to assemble such data hold promise for future studies. 